\title{
Adolescent idiopathic scoliosis (AIS), environment, exposome and epigenetics: a molecular perspective of postnatal normal spinal growth and the etiopathogenesis of AIS with consideration of a network approach and possible implications for medical therapy
}

\author{
R Geoffrey Burwell ${ }^{1 *}$, Peter H Dangerfield ${ }^{2,3,4}$, Alan Moulton ${ }^{5}$ and Theodoros B Grivas ${ }^{6}$
}

\begin{abstract}
Genetic factors are believed to play an important role in the etiology of adolescent idiopathic scoliosis (AIS). Discordant findings for monozygotic (MZ) twins with AIS show that environmental factors including different intrauterine environments are important in etiology, but what these environmental factors may be is unknown. Recent evidence for common chronic non-communicable diseases suggests epigenetic differences may underlie MZ twin discordance, and be the link between environmental factors and phenotypic differences. DNA methylation is one important epigenetic mechanism operating at the interface between genome and environment to regulate phenotypic plasticity with a complex regulation across the genome during the first decade of life. The word exposome refers to the totality of environmental exposures from conception onwards, comprising factors in external and internal environments. The word exposome is used here also in relation to physiologic and etiopathogenetic factors that affect normal spinal growth and may induce the deformity of AIS. In normal postnatal spinal growth we propose a new term and concept, physiologic growth-plate exposome for the normal processes particularly of the internal environments that may have epigenetic effects on growth plates of vertebrae. In AIS, we propose a new term and concept pathophysiologic scoliogenic exposome for the abnormal processes in molecular pathways particularly of the internal environment currently expressed as etiopathogenetic hypotheses; these are suggested to have deforming effects on the growth plates of vertebrae at cell, tissue, structure and/or organ levels that are considered to be epigenetic. New research is required for chromatin modifications including DNA methylation in AIS subjects and vertebral growth plates excised at surgery. In addition, consideration is needed for a possible network approach to etiopathogenesis by constructing AIS diseasomes. These approaches may lead through screening, genetic, epigenetic, biochemical, metabolic phenotypes and pharmacogenomic research to identify susceptible individuals at risk and modulate abnormal molecular pathways of AIS. The potential of epigeneticbased medical therapy for AIS cannot be assessed at present, and must await new research derived from the evaluation of epigenetic concepts of spinal growth in health and deformity. The tenets outlined here for AIS are applicable to other musculoskeletal growth disorders including infantile and juvenile idiopathic scoliosis.
\end{abstract}

\footnotetext{
* Correspondence: gburwell@tiscali.co.uk

'Centre for Spinal Studies and Surgery, Nottingham University Hospitals Trust, Queen's Medical Centre Campus, Derby Road, Nottingham, NG7 2UH, UK

Full list of author information is available at the end of the article
} 


\section{Introduction}

The principal aim of this paper is to examine the etiopathogenesis of adolescent idiopathic scoliosis (AIS) from the standpoint of epigenetics. To our knowledge this has not previously been addressed. Epigenetics, a relatively recent field now vast and vigorous, evaluates factors concerned with gene expression in relation to environment, disease, normal development and aging, with a complex regulation across the genome during the first decade of life. Butcher and Beck [1] describe epigenetics as follows:

"Although environmental measures are logical covariants for genotype-phenotype investigations, another nongenetic intermediary exists: epigenetics. Epigenetics is the analysis of somatically-acquired and, in some cases, transgenerationally inherited epigenetic modifications that regulate gene expression, and offers to bridge the gap between genetics and environment to understand phenotype. The most widely studied epigenetic mark is DNA methylation. Aberrant methylation at gene promoters is strongly implicated in disease etiology, most notably cancer."

There is controversy relating to the definition of epigenetics which we outline. Taking the broad definition, a view of AIS etiopathogenesis and normal spinal development is presented from an epigenetic standpoint, predicated on a model for other diseases.

Research into the causation of adolescent idiopathic scoliosis (AIS) draws heavily from mechanical and biological disciplines, but still lacks an agreed theory of etiopathogenesis [2,3]. Genetic factors are believed to play an important role in the etiology of AIS with considerable heterogeneity $[2,4,5]$. Hence treatment is empirical and not based on sufficient understanding of etiology to support the current mechanically-based therapy [6]. The research problem is complicated by the suspicion that AIS may result not from one cause, but several that interact. Genetic, and now genomic, research on AIS has not yet provided the therapeutically-required etiologic understanding. In other diseases and particularly diseases of developmental origin [7-13] and late-onset chronic non-communcable diseases (NCDs) [14-22], research on the role of environmental factors and epigenetics after a slow start [23] has exploded in the last decade $[1,17,18,24-32]$. Not so for AIS research where, except for monozygotic twin studies and very recent mentions on the net $[33,34]$, there are only sporadic reports suggesting that environmental factors are at work in etiology.

Genotype-environment (GxE, nature/nurture) interactions are being extensively researched in human growth [35-40], behavioural studies [41-43], early-life conditions [7-13,44,45], placentation [29] and gastrointestinal diseases [46-48]. The increasing incidence of idiopathic club foot in Denmark and Sweden has led to the speculation that factors associated with population density namely, environmental stress (traffic pollution, noise) and stress of urban living (misuse of tobacco, alcohol, drugs), could be reasons for this epidemiological change [49].

DNA methylation (DNAm) is an important epigenetic mechanism operating at the interface between genome and environment to regulate phenotypic plasticity with a complex regulation across the genome during the first decade of life [50]. Recent data suggests that epigenetic responses including DNAm is involved not only in cellular differentiation but also in modulation of genome function in response to signals from the various environments [45]. The window of developmental plasticity extends from preconception to early childhood and is exerted particularly during life-history phase transitions [13]. Developmental origins of health and disease and life-history transitions are purported to use placental, nutritional, and endocrine cues for setting long-term biological, mental and behavioural strategies in response to local physical, biological and/or social conditions $[13,45,51]$.

Epigenetics is now generally defined as information heritable during cell division but not contained within the DNA sequence itself [14]. There are three major ways organisms alter their DNAs inherited messages: enzymes methylate DNA to modulate transcription; histone modifications and nucleosome positioning to induce or repress target sequences; and non-coding small RNAs (including microRNAs and short interfering RNAs) which attach themselves to messenger RNA to modify the expression of specific genes $[10,46,52,53]$. DNA-cytosine methylation is a central epigenetic modification that has essential roles in cellular processes including genome regulation, development and disease [54]. According to Cropley et al [55] epigenetic mechanisms provide multicellular organisms with a system of normal gene regulation that silences portions of the genome and keeps them silent as tissues differentiate. Long-term silencing can be reprogrammed by demethylation of DNA which starts afresh in each generation in germ cells and early embryos through which effects on nutrition in utero may influence health in later life [56-58] (Appendix I).

Errors in this complex system termed epimutations arising from environmental and stochastic (random) events, can give rise to abnormal gene silencing, that may result in a great deal of phenotypic variation and common disease, At present, there are only a handful of clear examples; but importantly this can occur in the absence of any underlying genetic defect [59]. Alterations in the epigenetic status can be directly modified by various environmental insults or maternal dietary factors 
$[44,60]$. Epigenetics helps to explain the relationship between an individual's genetic background, environment, aging, and disease [17]. Sex differences in epigenetic processes may alter the risk or resilience to develop a particular disorder [61]. Increased understanding of epigenetic-disease mechanisms could lead to innovative diagnostic tests and disease-risk stratification to targeted intervention and therapies $[16,46]$.

The Human Epigenome Project (HE) and other epigenomic projects [62-66] are evaluating epigenetics in developmental origins of human disease $[9,11]$, and for musculoskeletal disorders in bone development [67-69] and dysmorphology [70].

Apart from the emerging role of epigenetic mechanisms in the etiology of neural tube defects [60], Prader-Willi syndrome $[71,72]$, and the recent theoretical interpretations of Burwell and colleagues [73-76] and McMaster [77], epigenetics does not figure in any causal analysis of postnatal normal spinal growth, or in the etiopathogenesis of AIS (Figure 1), This reflects current scientific opinion that genetic rather than environmental factors determine the etiology of AIS in accordance with the genetic variant hypothesis of disease [17,78] (Appendix II).
In this paper we briefly evaluate postnatal normal spinal growth and the etiopathogenesis of AIS in relation to the epigenetic explosion and the terminologic disagreements; the latter arise from the different requirements of geneticists, molecular biologists, developmental biologists and pathogetieticists. Our interpretation for AIS attempts to overcome these difficulties. It is predicated on the premise that in all scolioses, idiopathic, and secondary, spinal deformity cannot occur without normal vertebral growth-plate function being compromised ultimately in three dimensions by abnormal processes. This focus on vertebral growth does not imply that asynchronous ribcage growth [79-83], intervertebral discs and vertebral bone may not contain factors in AIS pathogenesis. The tenets outlined here for AIS are applicable to other developmental growth disorders including infantile and juvenile idiopathic scoliosis.

The aims of this paper are:

1. To review sporadic reports suggesting that environmental factors are involved in AIS etiology.

2. To note that the risks of developing late-onset chronic non-communicable diseases (NCDs) including cancer, diabetes, cardiovascular disease, respiratory

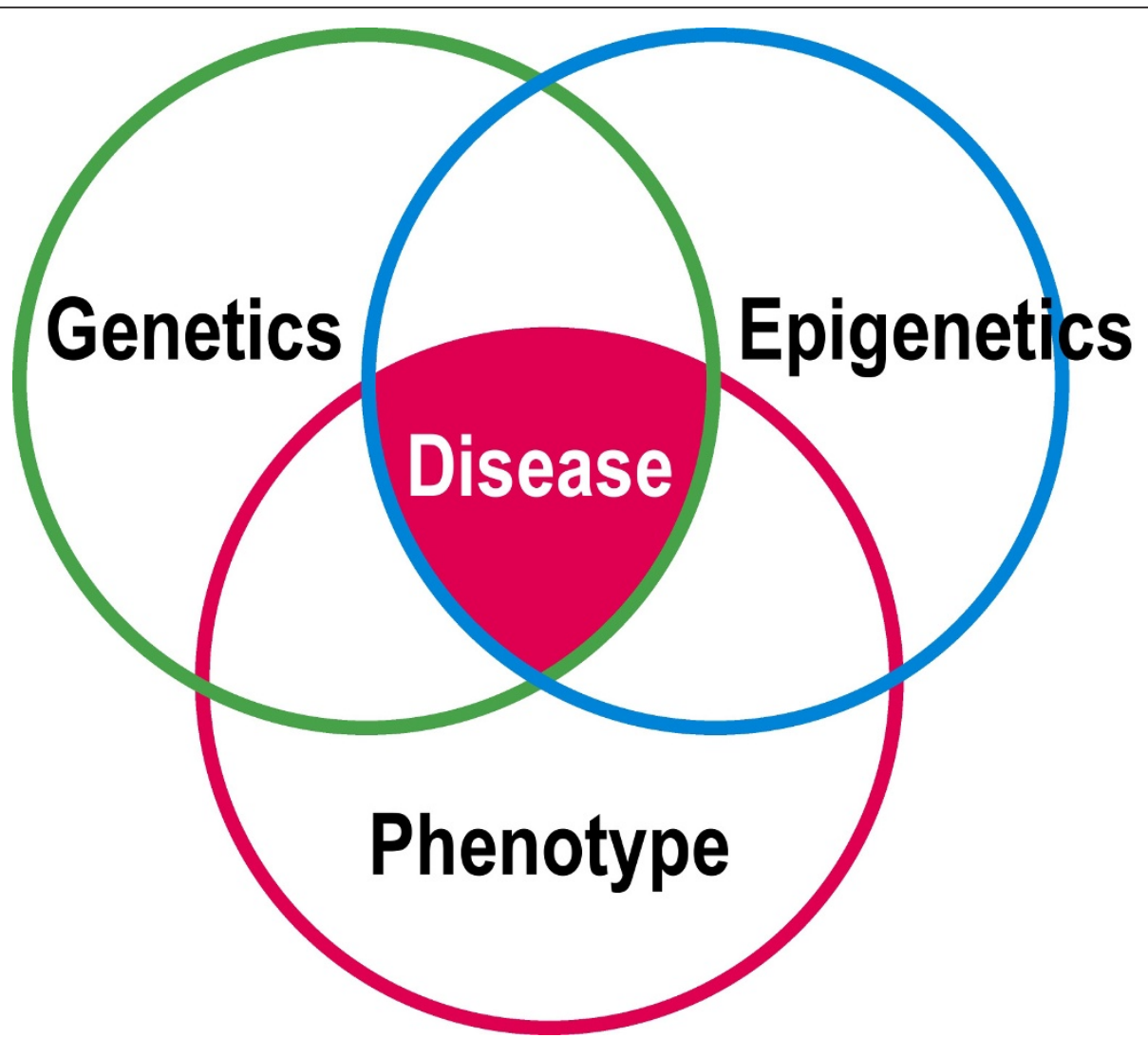

Figure 1 Venn diagram showing relationship between genetic variation, epigenetic variation and disease simultaneously (Modified from Feinberg [18]). 
disease, obesity and schizophrenia, are attributed to genetic and environmental factors.

3. To discuss the meaning of the word exposome. Currently, it refers to the totality of environmental exposures, exogenous and endogenous from conception onwards, some of which lead to occupational health problems.

4. To use the word exposome also in relation to physiologic and etiopathogenetic factors that respectively affect normal spinal growth and may induce/promote the deformity of AIS.

5. To suggest that the harmful effects produced by exposome factors leading to dysfunction involve interference with normal cellular processes and molecular pathways in cells, tissues, structures and organs.

6. To define epigenetics, its origin and two current meanings, modification and interactions.

7. To outline epigenetics in relation to normal embryonic development, involving epigenetic modification and interactions.

8. To present a causal analysis of the normal postnatal normal spinal growth putatively involving epigenetic interactions and modification.

9. To apply a new collective term and concept, physiologic growth-plate exposome, to the mainly endogenous (internal) environmental processes that affect normal spinal growth.

10. To present a causal analysis of abnormal deforming postnatal spinal growth in AIS, putatively involving epigenetic interactions and modification.

11. To apply a new collective term and concept, pathophysiologic scoliogenic exposome to abnormal processes in developmental pathways particularly of the internal environment that have putative epigenetic deforming effects on the growth plates of vertebrae at cell, tissue, structure and organ levels, and currently expressed as etiopathogenetic hypotheses.

12. To consider that the pathogenesis of AIS may involve a one-hit to multi-hit model.

13. To suggest research on chromatin modification including DNA methylation (DNAm) which plays an important role in gene expression, using tissues from AIS subjects including vertebral growth plates excised at surgery

14. To touch on network medicine and consider a network approach to AIS etiopathogenesis by constructing AIS diseasomes.

\section{Environmental risk factors for adolescent idiopathic scoliosis (AIS)}

Thirty years ago Wynne-Davies [84] examining the etiology of some common skeletal deformities including infantile idiopathic scoliosis, concluded that all are likely to have a common multifactorial genetic background associated with differing intrauterine or postnatal environmental factors. Most authors state that genetics stipulates the course of adolescent idiopathic scoliosis (AIS). In the last 20 years, sporadic reports have suggested environmental factors are involved in the etiopathogenesis and phenotypic expression of AIS. The evidence is outlined here together with an interpretation of AIS pathogenesis and the environment by some workers [85-87].

\section{Monozygotic (MZ) twins and spinal radiology in AIS}

MZ twins have a significantly higher concordance for AIS than dizygotic twins, with scoliosis curves in MZ twins developing and progressing together. Based on these data, Kesling and Reinker [88] concluded there is strong evidence for a genetic etiology for AIS, and familial idiopathic scoliosis [89,90].

MZ twins have been used to demonstrate the role of environmental factors in determining complex diseases and phenotypes, but the true nature of the phenotypic discordance remains poorly understood [24,50]. In AIS, concordance rates in MZ twins are 0.73-0.92 [88,91,92] with lower figures of 0.13 and 0.10 reported respectively from the Danish Twin Registry [93] and Swedish Twin Registry [94]. These findings are quite surprisingly different, and suggest that variation in diagnostic criteria is important in the results of these studies [Armour J personal communication]. The Swedish Twin Registry study revealed a unique environment effect of 0.60 [94] suggesting environmental factors are important in the etiology of AIS from different intrauterine environments [88]. In $32 \mathrm{MZ}$ twins, van Rhijn et al [95] found several parameters - gender, direction of convexity, apical level and kyphotic angle - were determined more by genetic factors than the lateral Cobb angle, suggesting that curve severity may be affected by the environment. Mirroring of curves was found in each of two MZ twin sets with idiopathic scoliosis $[88,96]$. In another MZ twin pair concordant for AIS, the twins had different apical levels, curve magnitudes, and age at detection which stress the importance of environmental (non-genetic) factors in etiopathogenesis [97].

Concordance rate of less than 100\% in MZ twins for AIS may be explained not only from environmental influences but also by other factors including, uneven cytoplasmic cleavage of the fertilized egg - thought to cause the scoliosis mirroring of one twin pair, mutation after fertilization causing a genotype mosaic [88], differences in placentation, amniotic sac, and vascularization of separate cell masses [24]. In MZ twins with congenital scoliosis, environmental factors are reported to play a leading role in the development of the condition [98].

According to Fraga et al [24] epigenetic differences may underlie MZ twin discordance for common diseases, and represent the link between environmental 
factors and phenotypic differences. The patterns of epigenetic modification of twin pairs diverge as they become older and their lifestyles become distinct reflecting accumulated exposure to a wide range of external and internal factors including environmental factors such as physical (and perhaps mental) activity, diet, drink, smoking and other habits [99]. They referred to the phenomenon as "epigenetic drift" and associated it with the aging process [100].

\section{A food and growth connection?}

A sudden increase in the incidence of idiopathic scoliosis in Jamaica after 1965 was evaluated by Golding [101]. Attention was directed to endocrine additives used to promote the growth of livestock and the meatto-food conversion in cattle and broilers. Taking Into consideration the 10-year delay in the onset of the idiopathic scoliosis, this fitted remarkably well with increase frequency of the scoliosis which occurred up to 1983 and its decline since.

Nutrition in the etiology of idiopathic scoliosis (IS)

A review of American and European articles from 19551990 evaluated nutrition as an environmental factor in the etiology of idiopathic scoliosis [102]. These authors concluded:

"...there is at least an anecdotal association of IS with poor nutrition, there is strong evidence from an animal model and there is a partial understanding of the biochemical mechanisms explaining nutrition as an etiological factor. Given the fact that nutrition is an environmental factor which can easily be changed, further investigation of the link between nutrition and IS in humans is warranted."

\section{Relative osteopenia and life-style factors}

Studies on Chinese girls with AIS have revealed relative osteopenia $[113,114]$ suggesting a contribution from lifestyle factors including nutrition, diet, calcium, vitamin D intake and exercise level [2]

Good dietary practices and optimal nutritional status are known to promote growth and tissue development, as well as disease prevention [39,53,103,104]. Nutritional epigenetics has emerged as a novel mechanism underlying gene-diet interactions [104] with the strongest evidence for transgenerational inheritance coming from the survivors of the Dutch Hunger Winter [105]. Dietary modification can have a profound effect on DNAm and genomic imprinting $[16,106]$, with plant-derived microRNAs entering the bloodstream [53]. A major focus of research on dietary influences on epigenetic status has been on nutrition in utero, because the epigenome is probably malleable particularly during this life-course window $[60,107,108]$, and because epigenetic marking by early exposures is a compelling mechanism underlying effects on lifelong health $[108,109]$. DNAm depends on dietary methionine and folate, both of which are affected by the nutritional state $[14,17,110]$. Ford et al [108] have published a Table summarizing specific dietary components with effects on DNAm; these include methyl donors, bioactive polyphenols, zinc, selenium, and vitamin A. In AIS, prevention by diet is discussed speculatively [111,112], and on the net [34].

\section{Physical activities of patients with AIS}

McMaster et al $[115,116]$ reported AIS to be negatively associated with participation in dance, skating, gymnastics/karate and horse riding classes. They asked the question: Do children who develop AIS have a longstanding proprioception defect which makes them less likely to participate in sporting activities? If so, by encouraging sport and increasing proprioceptive abilities common to all joints [117] might make those at risk less likely to develop spinal asymmetry.

\section{Geographic latitude and the prevalence of AIS}

In a review of peer-reviewed published papers, Grivas et al [118] found that a later age at menarche is associated with a higher prevalence of AIS. The prevalence decreases as geographic latitude approaches the equator, suggesting a possible role for environmental factors in the pathogenesis of AIS in girls. A slight delay of menarcheal age in northern countries by lengthening the period of spine vulnerability to etiologic factors, was suggested as a pathogenetic mechanism.

\section{Maternal age and socio-economic status}

In a study of 404 children with idiopathic scoliosis predominantly from New York State there was an excess of propositi born to mothers at ages 30-39 years [119]. Wynne-Davies $[89,120]$ reviewing 94 children with AIS found in girls and boys, maternal but not paternal age was significantly in excess of normal. In a Swedish study of perinatal and environmental aspects of 551 adolescent patients with thoracic idiopathic scoliosis, maternal age was higher, birth weight normal, scoliosis commoner in higher socioeconomic groups, and the illegitimacy rate half that expected [121]. These findings from the USA, Scotland and Sweden are consistent and reveal increased maternal age as a risk factor for AIS, suggesting maternal factors can predispose to it. The intra-uterine environment is crucial in programming the fetus for various health and disease outcomes throughout life [44].

Heated indoor swimming pools infants and delayed epigenetic effects

In a case-control study in Scotland, McMaster et al $[115,116,122]$ reported a statistically significant correlation between the introduction of infants to heated indoor swimming pools and the development of AIS. A neurogenic hypothesis was formulated to explain how toxins produced by chlorine in such pools may act on the infant's immature central nervous system; through vulnerability of the developing brain to circulating toxins and delayed epigenetic effects with the bony trunk 
deformity of AIS not becoming evident until adolescence [77]. There may be many such environmental factors acting in the first year of life to initiate AIS and differing around the world, with one environmental factor involving heated indoor swimming pools being detected in Scotland [77]. Whatever effects the neurotoxic products may have on the immature brain, the process of puberty with its increased growth velocity is suggested to play a role in the delayed phenotypic expression of AIS [77].

\section{Non-surgical treatments for AIS}

Publications on environmental effects induced in the spine by physical exercises and brace treatments will not be considered here.

\section{Hypothesis of developmental instability for scoliosis}

Speculation that genetic and environmental factors are involved the etiopathogenesis of idiopathic scoliosis $[123,124]$ was developed by Goldberg and colleagues [85-87] who suggested that scoliosis is caused by environmental stress causing developmental instability:

"....scoliosis is not a disease or group of diseases but a symptom or sign of environmental stress, significant enough to overwhelm the intrinsic stability of the morphological genome. As such, there is no specific etiology but a large number of precipitating stressors...."[87].

Such environmental factors could be hormonal, nutritional, alcohol, smoking, viruses, drugs, medicaments, radiation, maternal reactivity to male-specific features of the fetus, hypoxia during birth [111], factors associated with population density [49], toxins in heated indoor swimming pool [77], and lack of physical activity. $[115,116]$.

The hypothesis of devevlopmental instability applied to scoliosis is contained within both the developmental origins of health and disease concept (DOHaD) $[9,12,13]$ and the common disease genetic and epigenetic model for late-onset chronic non-communicable diseases (CDGE) [14,17]. Both the DOHaD and CDGE models for disease invoke epigenetic mechanisms [125] (Appendix III).

\section{Chronic diseases, external and internal environments, phnotypic plasticity, exposome}

The risks of developing late-onset chronic non-communicable diseases (NCDs) including cancer, diabetes, cardiovascular disease, respiratory disease, obesity and schizophrenia, are attributed to both genetic and environmental factors; $70-90 \%$ of disease risks are thought to be due to differences in environments $[19,126]$. Hanson et al [20] comment that progress in this field has been slow due to an excessive emphasis on fixed genomic variations (hard inheritance) as the major determinants of disease susceptibility. However, new evidence demonstrates the much greater importance of early-life developmental factors, involving epigenetic processes and 'soft' inheritance in modulating an individual's vulnerability to NCDs. According to Rappaport and Smith [19] epidemiologists increasingly use genome-wide association studies (GWAS) to investigate NCDs, and rely on questionnaires to characterize "environmental exposures". The risk factors for NCDs include smoking, unhealthy diet, lack of physical activity and alcohol abuse $[21,22]$.

\section{Exposome}

The word exposome [127] refers to the totality of environmental exposures from conception onwards that create dysfunction which in some individuals leads to occupational health problems [128]. The exposome comprises exogenous and endogenous factors: exogenous factors in the external environment - chemicals (toxicants) entering the body from air, water and food, eg diet, food supplements, life style, drugs, chemicals; and endogenous factors in the internal environment - chemicals produced in the body eg, oxidative stress, lipid peroxidation $[111,112,129]$, gut flora, and other natural processes, including biomarkers. Any harmful effects leading to dysfunction evidently interferes with normal cellular processes and molecular pathways in cells, tissues, structures and organs with the individual response to environmental factors being genetically influenced [129]. There are likely to be critical periods of exposure in development with vulnerability to the exposome [126]. Human evolution through natural selection has involved reduced exposure to challenges from external and internal environments [130].

\section{Definitiions: epigenetics, origin and its recent double meaning in health and disease}

Epigenesis in biology describes the morphogenesis and development of an organism with organ systems that are not preformed.

\section{Epigenetics}

The word epigenetics was coined by Waddington [131] to link the two fields of developmental biology and genetics, hitherto considered as separate disciplines [132-134]. There are now several definitions of epigenetics [14,18,25,135-140] (Appendix IV). Waddington's broad view of epigenetics fell out of favor in modern biology to be replaced with a much narrower one defining epigenetics as:

".... modifications of the DNA or associated proteins, other than DNA sequence variation, that carry information content during cell division." [10,14,17,25,29].

These changes result from chemical alterations to DNA or associated histone proteins termed epigenetic modification, occurring in health and disease from stochastic (random) and environmental factors modulating transcription from chromatin $[29,141]$. The best known 
example of epigenetic modification is DNA methylation (DNAm). Cell type-specific DNAm patterns are established during mammalian development and maintained by tissue-specific gene expression in adult somatic cells [142]. DNAm plays an important role in programming gene expression, including the regulation of changes in gene expression in response to aging and environmental signals $[104,143]$. Loss of methylation, which may result from enzymic mechanisms will lead to heritable abnormalities in gene expression, and these may be important in oncogenesis and aging [104,142-144].

Methylome refers to the genome-wide state of DNAm [18]. Advances in sequencing methods have allowed measurement of the first complete genome-wide DNAm map (methylome) in human cells $[54,145,146]$.

Epigenotype refers to information in a cell that is maintained through mitosis and/or meiosis but does not involve DNA sequence itself [14].

Epigenome, is the sum total of all the epigenetic information in a cell; there are as many epigenomes as there are cell types [26]. It has been likened to an archive of the prenatal environment [44]. The epigenome parallels the word genome, and refers to the overall epigenetic state of a cell. Although all (nucleated) human cells effectively contain the same genome (and therefore the same genetic instruction sets), they contain very different epigenomes depending upon cell type, developmental stage, sex, age, environmental cues, various other parameters and maintain different terminal phenotypes $[147,148]$. Epigenomics refers to the genome-scale analysis of epigenetic marks [18].

Epimutations and disease. According to Martin et al [59], epigenetic silencing is a pervasive mode of gene regulation in multicellular animals. Epigenetic silencing is not irreversible and requires active maintenance. This requirement for active maintenance of epigenetic states, creates the potential for errors on a large scale. When epigenetic errors - or epimutations - activate or inactivate a critical gene, they may cause disease. They define epigenetic disease as: "...one caused by stable alteration in the epigenetic state of a gene (epimutation) without any contributory genetic mutation."

Epigenetic modification and interactions. Very recently, some workers have returned to using Waddington's more inclusive definition to bridge more fully the gap between genotype and phenotype, introducing the term epigenetic interactions [138-140,149]. This concept does not entirely accord with the view that an epigenetic system should be heritable, self-perpetuating and reversible [141]. Whether or not the term epigenetics retains its original meaning or becomes restricted to chromatin modification remains to be seen [149]. Taken together both terms, modification and interactions, enrich and broaden our view of development, evolution and disease [149].
How may these new epigenetic concepts of modification and interactions be related to normal development?

\section{Epigenetics - relevance for normal development}

Developmental biology and embryonic development. Figure 2 shows that in normal embryonic development, epigenetic changes may occur at each of cell, tissue, structure and organ levels. A cell's environment, location and surroundings provide epigenetic factors that influence the cell's identity and activities [119] as it rolls down Waddington's metaphorical epigenetic landscape [150]. Francis [151] states that the fate of each cell is largely determined by its position in the embryo and the nature of its neighbour cells with which it chemically interacts; this is termed patterning in skull development $[74,75,138,139]$. These intercellular interactions influence the environment within the cell, which in turn influences which genes are epigenetically activated or inactivated. At organ level, the growing brain influences the development of the skull presumably involving mechanical interaction (mechanotransduction) as an epigenetic interaction $[137,140]$.

\section{Epigenetic modifications and regulation}

Figure 3[152-154] shows predominant epigenetic modifications: DNA methylation (DNAm) modifications to histones, non-coding RNAs and parent-of-origin imprinting for placental development. (Appendix V) [155-172] [see Figure 2, reference [10] and [29,46,141,153]].

\section{Epigenetic interactions}

Figure 4 shows epigenetic interactions for normal vertebral growth constructed mostly from the descriptions of Herring [136,137] and Lieberman [138,139], and for chemicals from other workers [173-175].(Appendices IV \& VI).

How may epigenetic modification and interactions relate to normal postnatal spine growth?

\section{Normal postnatal spine development - physiologic growth-plate exposome}

Figure 5 shows factors that affect growth of the normal spine through vertebral growth plates. They are shown as three groups: genetic, internal environment, and external environment. Besides genetic control, the growth of normal vertebral growth plates is influenced by factors mainly within the internal environment; these include hormones $[133,136,176,177]$, growth factors [176] chemicals [173-175] and mechanical forces $[133,136,137,178,179]$; the latter are created by the vertebral growth force $[136,180]$, gravity (a weak force [181-183], upright posture and muscular contractions under central nervous system control acting against gravity. External environmental factors include gravity, nutrition and lifestyle. 


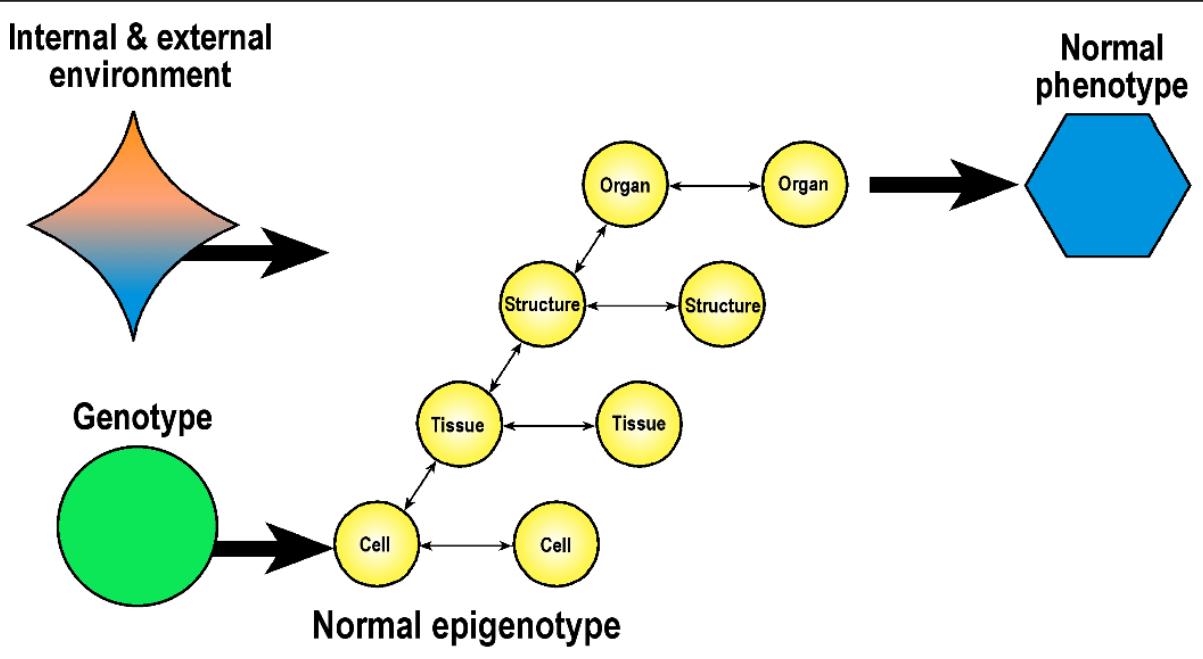

\section{Time in embryonic development}

Figure 2 Normal embryonic development over time initiated by genetic factors (green) and environmental factors (internal blue, external orange ) leading to the normal phenotype (blue). Small arrows represent epigenetic interactions occurring at call, tissue, structure and organ levels (Modified from Jamniczky et al [140]).

We propose the term, physiologic growth-plate exposome for the mainly internal normal environmental processes that affect normal spinal growth. The effects of this physiologic exposome on vertebral growth plates is viewed as epigenetic. This will involve epigenetic interactions. How much epigenetic modification is involved is unknown.

\section{Adolescent idiopathic scoliosis - pathophysiologic} scoliogenic exposome

Figure 5 shows etiopathogenetic hypotheses for AIS which express abnormality(ies) in normal developmental pathways of one or more of the normal internal environmental processes. Whether one (one-hit model) or several (multi-hit model) abnormalities are involved in

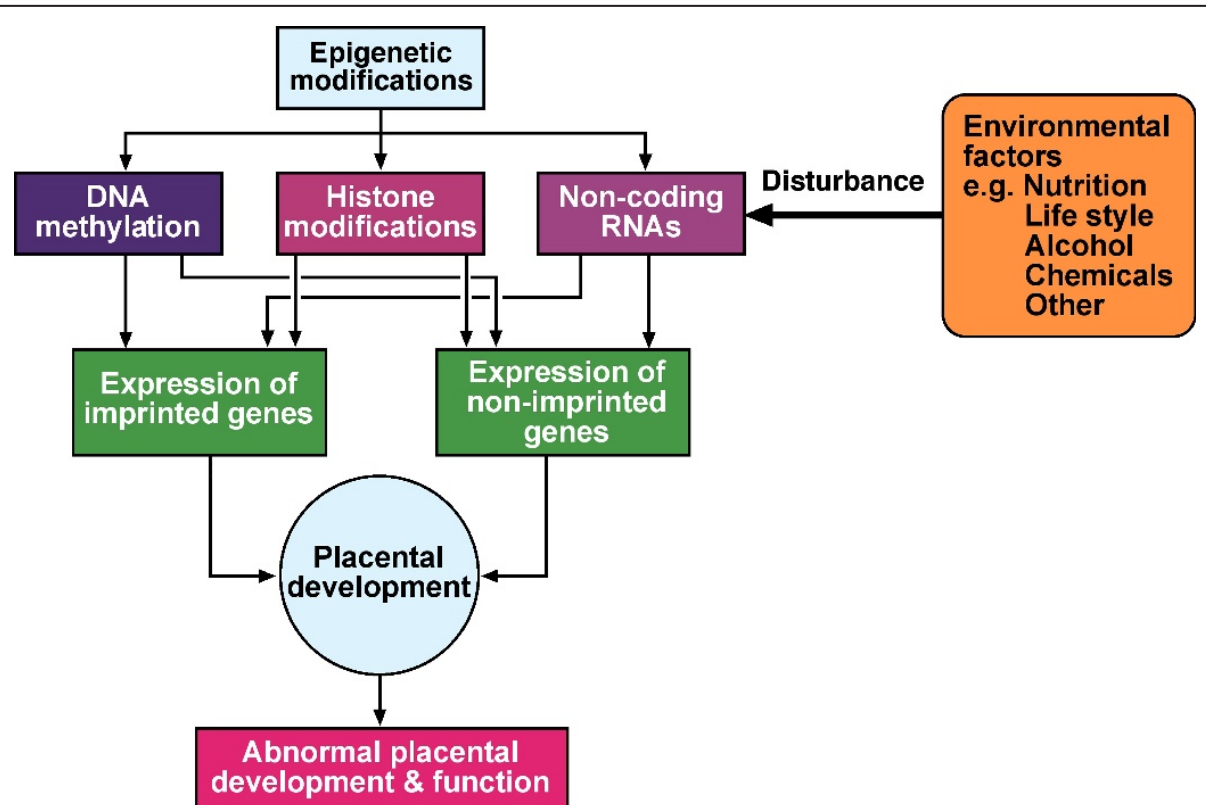

Figure 3 Epigenetic modifications in placental development and possible consequences of its disturbance which can be caused by environmental factors. X-chromosome inactivation (lyonization) is not shown [152-154] (Modified from Nelissen et al [29]). 


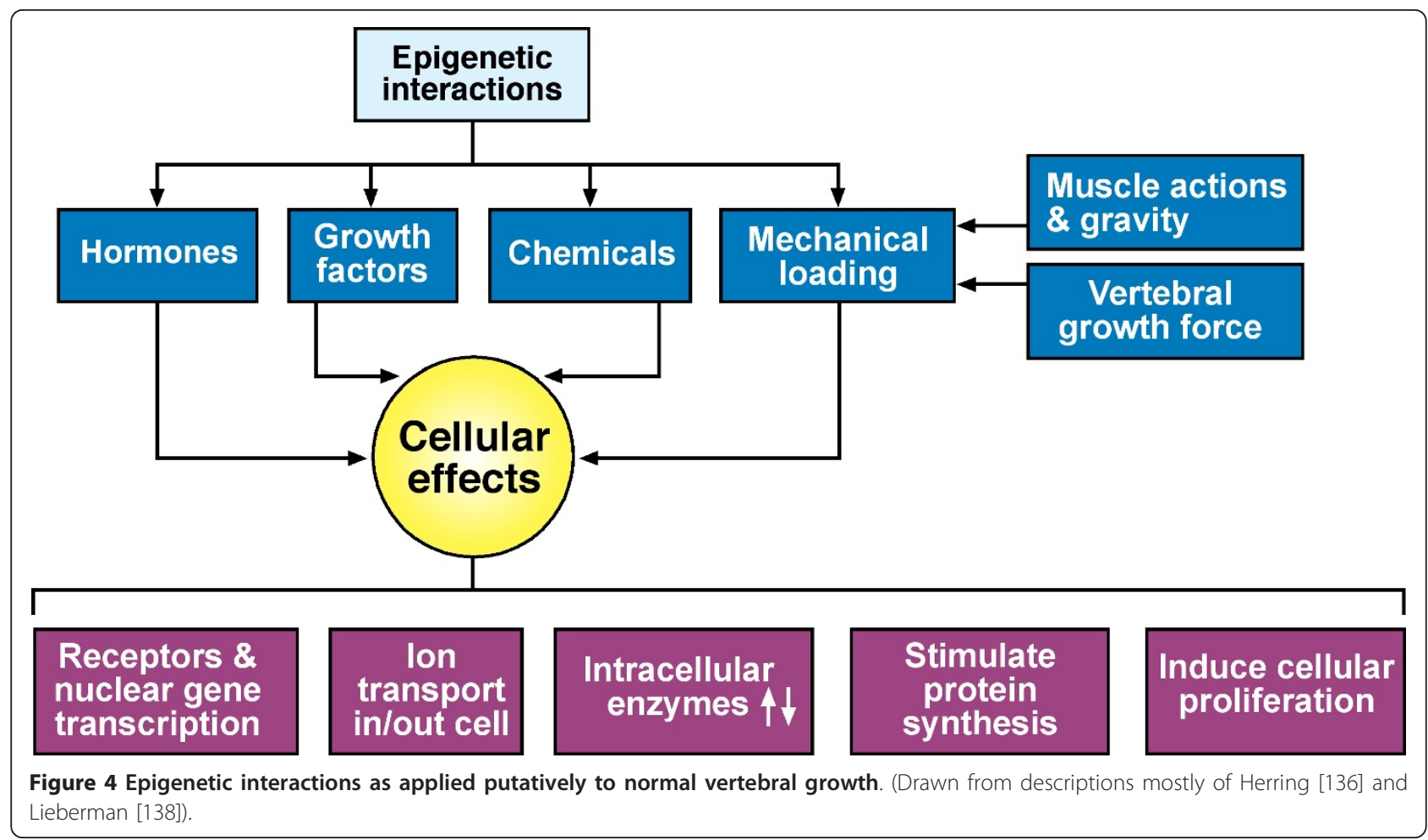

pathogeenesis for different individuals with AIS is unknown. We propose a new term and concept, pathophysiologic scoliogenic exposome be applied to abnormal processes in normal developmental pathways particularly of the internal environment that have putative epigenetic deforming effects on the growth plates of vertebrae [184-191] at cell, tissue, structure and organ levels, and currently expressed as etiopathogenetic hypotheses (Appendix VII) [192-242]. This will involve epigenetic interactions. How much epigenetic modification is involved is unknown.

Figure 6 shows etiopathogenetic hypotheses acting at cell, tissue, structure and organ levels linked to possible epigenetic mechanisms affecting vertebral growth plates, possibly in a diverse network of developmental pathways [243].

Trunk velocity of growth and asymmetric internal pressure as environmental stress

Trunk growth, hormonally stimulated, provides an important internal environment in which scoliosis curves progress [96]. Likewise, asymmetric internal pressure of the intervertebral disc and vertebral growth plate in scoliosis suggests an abnormal stress environment generates a positive feedback of cellular changes, resulting in curve progression due to a combination of factors $[244,245]$. These will include cyclical loads and asymmetrical changes in disc fluid content which affect vertebral growth (deforming three joint complex) [222].

\section{Pathogenic asymmetry inducing and exacerbating} processes

AIS asymmetry-inducing processes $[238,240]$ - be they mechanical or biological - affecting vertebral growth plates, may render other factors including velocity of growth and hormones, abnormally increased or physiologic $[3,6]$, to exacerbate the scoliotic deformity [243]. The etiologic, and potentially therapeutic, problem is to establish in each AIS girl, which process(es) in what pathway(s), is (are) abnormal, or exacerbating the deformity.

\section{Longitudinal studies}

In a cohort of normal individuals born in the UK in 1946 and surveyed longitudinally to the present, research is in hand to analyse tens of thousands of possible methylation sites in the DNA looking for changes that could explain the link between birth weight and breast cancer risk [246]. A similar study could evaluate AIS subjects.

\section{Epigenetics at the epicenter of modern medicine} Feinberg [17] writes:

"Epigenetics, the study of non-DNA sequence-related heredity, is at the epicenter of modern medicine because it can help to explain the relationship between an individual's genetic background, the environment, aging, and disease..." (see Appendix II). 


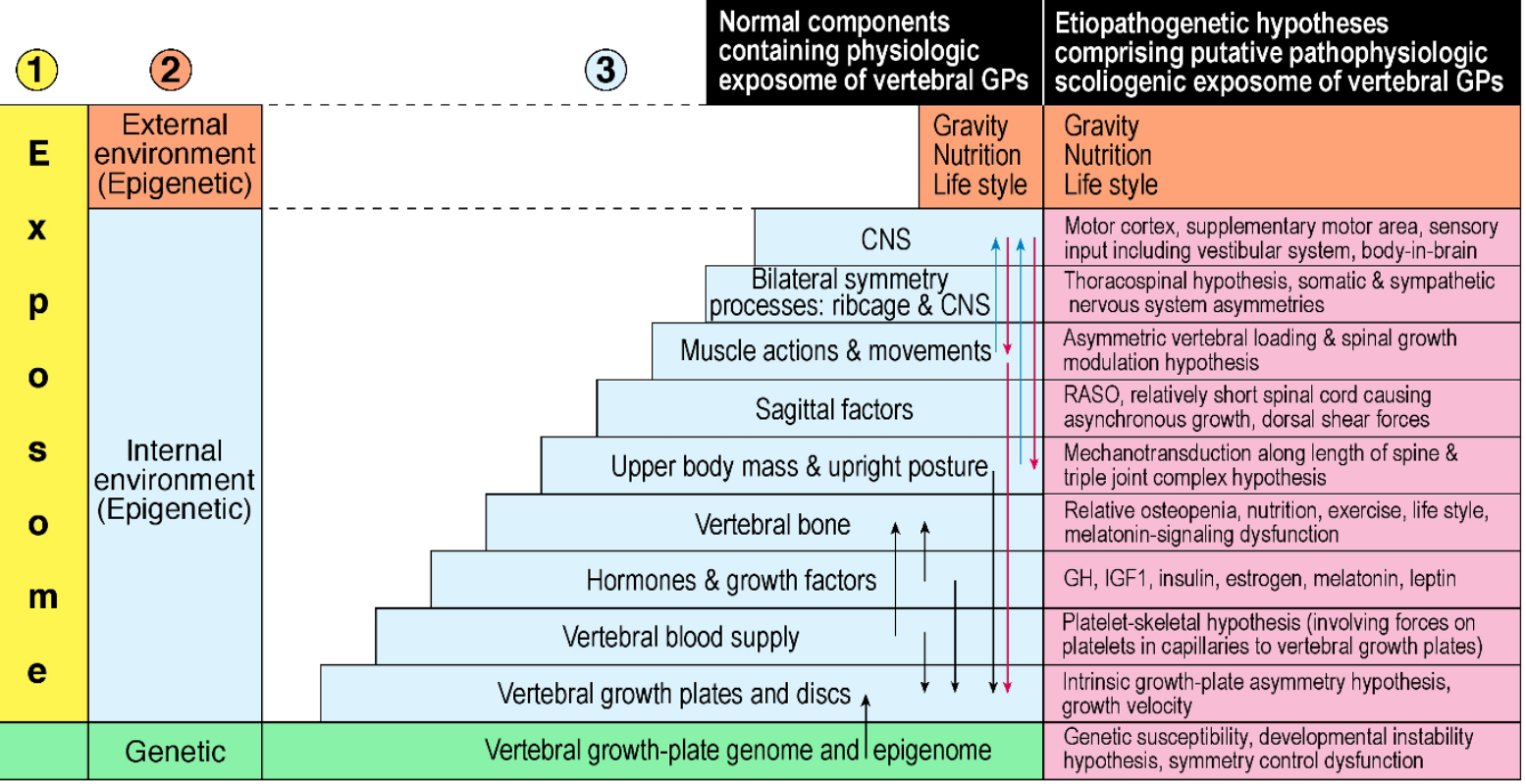

Figure 5 Putative genetic and epigenetic approach to causal factors affecting vertebral growth plates (GPs) in health and AIS pathogenesis (CNS = central nervous system). Moving from left-to-right in columns: 1) Exposome (yellow); 2) external environment (epigenetic, orange), internal environment (epigenetic, blue) and genetic (green); 3) factors controlling normal vertebral growth, genetic (green), internal environment (blue) and external environment (orange) containing the physiologic growth-plate exposome; these factors are considered to cause epigenetic changes (follow vertical arrows) in normal structures and contribute to the epigenome of vertebral growth plate cells; 4) etiopathogenetic hypotheses for AIS containing the pathophysiologic scoliogenic exposome (pink) and genetic susceptibility (pink); 5) the resulting AIS deformity (red); 6) the long vertical red arrow to the right represents craniocaudal pathophysiologic components affecting the trunk over time leading to the AIS deformity. (Adapted to normal spinal growth and AIS pathogenesis from the multihit pathogenetic model for inflammatory bowel disease of Maloy and Powrie [47] and the genetic/epigenetic model for common human diseases of Bjornsson et al [14]).

The therapeutic potential of epigenetics for preventing and treating common human illness is threefold [17].

1) The possibility of new therapies because epigenetic changes are by definition reversible, unlike sequence mutations in disease.

2) Using medication to target biochemical pathways that are disturbed epigenetically in disease.

3) To intervene at the junction between genome and environment, to modify the effects of deleterious genes, and to influence the effects of the environment on phenotypic plasticity - ie, cells' ability to change their behavior in response to internal or external environmental cues.

The potential of these therapeutic and epigenetic epidemiologic approaches to AIS is at present unknown, and is restricted by the absence of established environmental factors involved in its etiopathogenesis.

\section{Network medicine and AIS}

Barabasi [247] introduced the term network medicine which provides a network-based approach to human diseases by constructing diseasomes. According to Barabasi et al [248] given the functional interdependencies between the molecular components in a human cell, a disease is rarely a consequence of an abnormality in a single gene, but reflects the perturbations of the complex intracellular and intercellular network that links tissue and organ systems. Interactome describes the complex biological systems and cellular networks within cells [249].

Barabasi [247] states that network analysis is poised to play its biggest role at the cellular level since most cellular components are connected to each other through intricate regulatory metabolic and protein-protein interactions with proteomic assessment where research is 


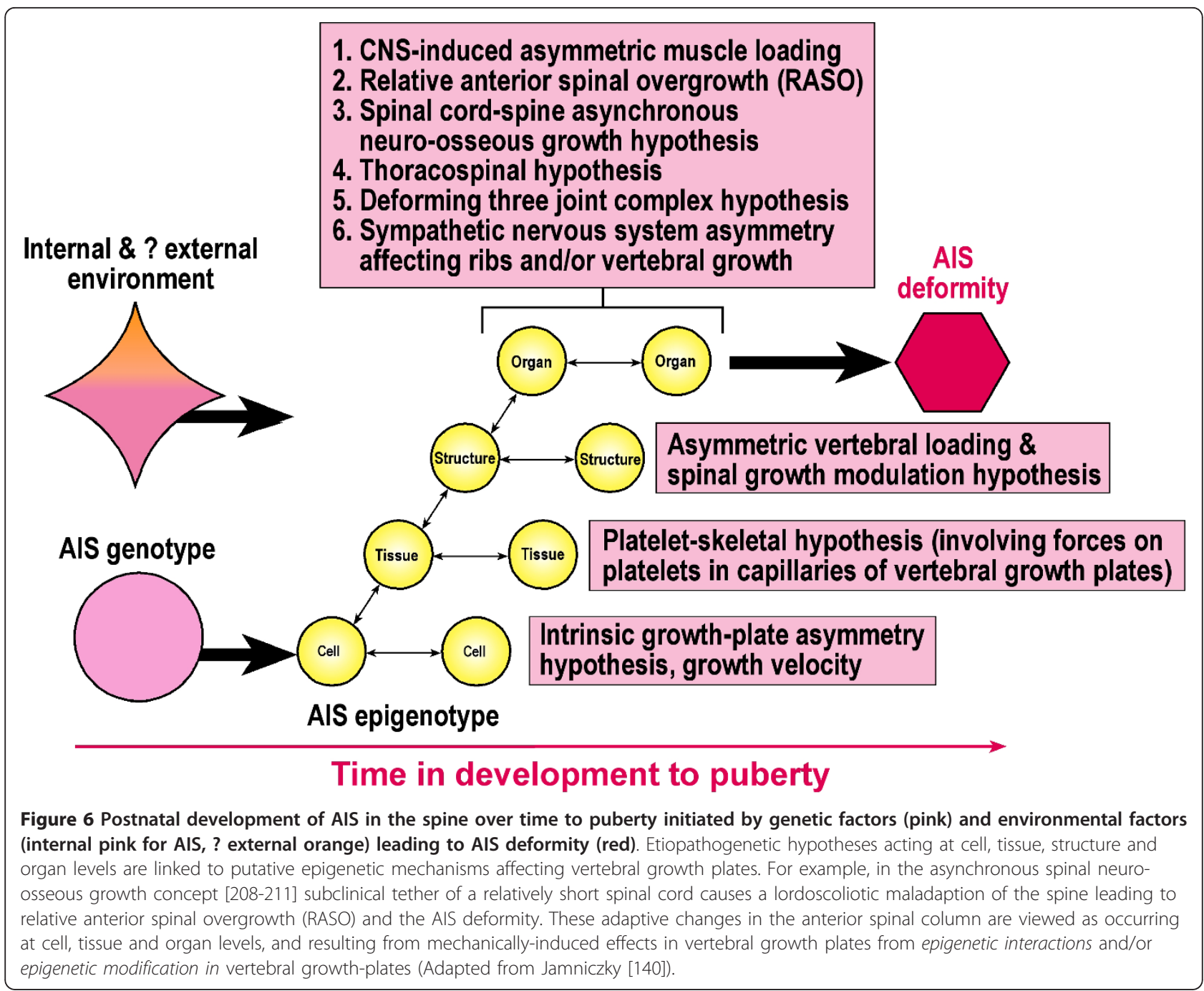

needed [3,250]. The paradigm of network medicine is, "think globally, act locally".[248].

In AIS, consideration is needed for the possible creation of a network approach to etiopathogenesis by constructing AIS diseasomes.

\section{Summary and Conclusions}

1. Genetic factors are believed to play an important role in the etiology of AIS in accordance with the genetic variant hypothesis of disease.

2. Sporadic reports, particularly for monozygotic twins but also other findings, suggest environmental factors are involved in the etiopathogenesis and phenotypic expression of AIS.

3. Research on the role of environmental factors and epigenetics has exploded in the last decade but not so for AIS (Figure 1).

4. Apart from the emerging role of epigenetic mechanisms in the etiology of neural tube defects [60], the Prader-Willi syndrome [71,72], and theoretical interpretations of Burwell and colleagues [73-76] and McMaster [77], epigenetics does not figure in any causal analysis of postnatal normal spinal growth, or in the etiopathogenesis of AIS (Figure 1).

5. There are three major ways organisms modify their DNAs inherited messages without changing DNA sequence: enzymes methylate DNA to modulate transcription; histone modifications and nucleosome positioning to induce or repress target sequences; and non-coding small RNAs to modify the expression of specific genes where there is therapeutic potential (Figure 3, Appendix V)

6. DNA methylation is an important epigenetic mechanism operating at the interface between genome and environment to regulate phenotypic plasticity with a complex regulation across the genome during the first decade of life

7. DNA methylation depends on dietary methionine and folate, both of which are affected by the nutritional state of the individual. 
8. Epigenetic modification provides multicellular organisms with a system of normal gene regulation that silences portions of the genome and keeps them silent as tissues differentiate as epigenotypes (Figure 3).

9. Errors in this complex system from environmental and stochastic (random) events termed epimutations can give rise to abnormal gene silencing, that may result in a great deal of phenotypic variation and common disease.

10. Epigenetic interactions operating at cell, tissue, structure and organ levels, have been defined very recently by some workers in keeping with Waddington's inclusive definition of epigeneticss; the term is used to describe additional mechanisms for modulating cellular effects in response to changes in the internal and external environments without altering DNA sequence (Figure 4).

11. A molecular perspective encompassing epigenetic modification and interactions at vertebral growth plates for normal postnatal spinal growth and the etiopathogenesis of AIS is given.

12. The word exposome, means the totality of environmental exposures, external and internal, from conception onwards that create dysfunction leading in some individuals to occupational health problems,

13. The woed exposome is used here also in relation to physiologic and etiopathogenetic factors that respectively affect normal spinal growth and may induce the deformity of AIS namely, physiologic growth-plate exposome and pathophysiologic scoliogenic exposome (Figures 5 \&6).

14. The concept of a one-hit to multi-hit model for AIS pathogenesis is mentioned.

\section{Future potential}

1. The potential of epigenetic-based medical therapy for AIS cannot be assessed at present. It must await new research derived from the evaluation of epigenetic concepts for spinal growth in health and deformity.

2. Consideration is needed for the creation of a network approach to AIS etiopathogenesis by constructing AIS diseasomes,

3. These approaches, epigenetic and network, may possibly lead through several approaches - screening, genetic [195,198,199,251], epigenetic, biochemical [3,173-175,229, 230], metabolic phenotypes [251] and pharmacogenomic $[5,251]$, to the modulation of abnormal molecular pathways $[108,179,252]$ by the development of novel preventive and curative measures based on diet, novel epigenetic drugs $[13,108]$ and other approaches [52].

4. The tenets outlined here for AIS etiopathogenesis are applicable to other musculoskeletal growth disorders, including infantile and juvenile idiopathic scoliosis.

\section{APPENDIX I}

Dual inheritance. Holliday [58] points out that genetic inheritance in higher organisms normally refers to the transmission of information from one generation to the next. Nevertheless, there is also inheritance in somatic cells, characterized by the phenotypic stability of differentiated cells that divide (such as fibroblasts and lymphocytes), and also mitosis of stem line cells, which gives rise to another stem line daughter cell, and one that will differentiate.

\section{APPENDIX ||}

Feinberg [18] places epigenetics in perspective as follows (Figure 1):

"Traditionally, the pathology of human disease has been focused on microscopic examination of affected tissues, chemical and biochemical analysis of biopsy samples, other available samples of convenience, such as blood, and noninvasive or invasive imaging of varying complexity, in order to classify disease and illuminate its mechanistic basis. The molecular age has complemented this armamentarium with gene expression arrays and selective analysis of individual genes. However, we are entering a new era of epigenomic profiling, i.e., genomescale analysis of cell-heritable nonsequence genetic change, such as DNAm. The epigenome offers access to stable measurements of cellular state and to biobanked material for large-scale epidemiological studies. Some of these genome-scale technologies are beginning to be applied to create the new field of epigenetic epidemiology."

According to Feinberg [18] the new filed of epigenetic epidemiology will measure and catalog epigenetic variation within and across populations in genome-scale analyses to characterize the correlation properties of methylation, similar to the catalog of SNP/CNV and linkage disequilibrium (non-random association of alleles at different loci), already showing promise in neuropsychiatric disease.

\section{APPENDIX III}

Phenotypic plasticity, time dependency and the CDGE, model for chronic disease. A common theme to disease epigenetics is the disruption of phenotypic plasticity; this is the ability of cells to change their behavior in response to internal or external environmental cues over time [12,14-16]. Feinberg and colleagues [14,17,18] suggested the hypothesis that epigenetics provides an added layer of variation that might mediate the relationship between genotype and internal and external environmental factors which they termed the common disease genetic and epigenetic hypothesis (CDGE). This conjectural model overlies the genetic hypothesis of disease with an epigenetic component interacting with it $[17,78]$. The CDGE, model better explains the age degeneration of epigenetic patterns than does the genetic hypothesis [14]. 
Genetic variant hypothesis of disease and non-genomic factors. Butcher and Beck [1] write:

"A spate of high-powered genome-wide association studies (GWAS) have recently identified numerous singlenucleotide polymorphisms (SNPs) robustly linked with complex disease. Despite interrogating the majority of common human variation, these SNPs only account for a small proportion of the phenotypic variance, which suggests genetic factors are acting in concert with nongenetic factors. Although environmental measures are logical covariants for genotype-phenotype investigations, another non-genetic intermediary exists: epigenetics." [see [125]].

\section{APPENDIX IV}

Haig [133] states that epigenetics has different meanings for different sciientists. Molecular biologists are familiar with the definition as:

"The study of mitotically and/or meiotically heritable changes in gene function that cannot be explained by changes in DNA sequence [135].

In contrast, functional morphologists would be more familiar with the definition:

"... the entire series of interactions among cells and cell products which leads to morphogenesis and differentiation." [136]. Herring continues, "Thus all cranial development is epigenetic... Among the numerous epigenetic factors influencing the vertebrate face is mechanical loading. Loading seems to be particularly significant for formation and growth of skeletal tissues... Epigenetic influences range from hormones and growth factors to ambient temperature and orientation in a gravitational field." [see [137-140]].

Feinberg [17] states that epigeneticss is at the heart of developmental biology, with the modern definition and Waddington's definition having converged. That is because "...the epigenetic state of an organism progresses from gamete to zygote to somatic tissue, all of which have profoundly different epigenomes, while the DNA is the same [18]. This view does not accommodate the concept of epigenetic interactions [137-140].

A few scientists take a more relaxed, or stricter view, either including RNA modification or limiting to vertical (generational) transmission [17].

Epigenetics does not invoke inheritance of mutational changes. leaving open what kinds of mechanism are at work [17]. An epigenetic system should be heritable, self-perpetuating and reversible [141]. Bird [25] wishing to avoid the constraints imposed by stringently requiring heritability in the definition of epigenetics, suggested the following:

"...the structural adaptation of chromosomal regions so as to register, signal or perpetuate altered activity states."

\section{APPENDIX V}

DNA methylation (DNAm). The predominant epigenetic mechanisms involve DNA methylation, modifications to chromatin, genomic imprinting $[106,155,156]$, and noncoding RNAs [46,52]. DNAm in mammals occurs almost exclusively as the covalent addition (or mark) of a methyl $\left(\mathrm{CH}_{3}\right)$ group mainly to the nucleotide cytosine at cytosine-guanine dinucleotide sequences catalyzed by DNA methyltransferases (CpG islands, where 'p' indicates interstitial phosphate group between the DNA bases $[10,17,26,29,63,141])$. Promoters are key targets for epigenetic modification [63]. There are also covalent modifications of DNA-bound histones [157,158], notably acetylation, phosphorylation, methylation and ubiquitination [1,159-161]. Cytosine methylations of gene promoters which are reversible, are generally associated with silencing of genes, whereas histone acetylations are generally associated with activation of genes $[26,99]$. Many groups have studied the genomic distribution of DNA cytosine methylation and other chemical modifications of histone proteins to the epigenome $[145,161]$. Imprinting leads to the mono-allelic expression of certain genes depending on the parent origin of the allele controlled by imprinting control regions marked by DNA and histone methylation on one of the two parent alleles, perturbations of which induce diseases, including the Prader-Willi syndrome [52]. Recently it has become appreciated that hydroxymethylation of cytosine is a minor, but prevalent, form of base modification in addition to 5-methylation [162].

DNAm and folic acid. The source of methyl groups for DNAm is methionine an essential amino acid that is converted to a biologically active methyl donor state, Sadenosylmethionine, through a pathway involving folic acid, both of which are affected by the nutritional state [17,108,110, see Figure 1 of [108]]. Findings in subjects with chronic kidney disease and uremia have established a link between the epigenetic control of gene expression and xenobiotic influences, such as folate therapy [163]. Accoeding to Park et al [104] nutrients involved in onecarbon metabolism, namely folate, vitamin B12, vitamin B6, riboflavin, methionine, choline and betaine, are involved in DNA methylation by regulating levels of the universal methyl donor S-adenosylmethionine and methyltransferase inhibitor S-adenosylhomocysteine. Other nutrients and bioactive food components such as retinoic acid, resveratrol, curcumin, sulforaphane and tea polyphenols can modulate epigenetic patterns by altering the levels of S-adenosylmethionine and S-adenosylhomocysteine or directing the enzymes that catalyse DNA methylation and histone modifications.

MicroRNAs, short interfering RNAs and potential for therapy. MicroRNAs (miRNAs) are a class of short 
endogenous non-coding RNAs that act as post-transcriptional regulators of gene expression by attaching themselves to messenger RNA [52]. MiRNAs play fundamental roles in the control of many biological processes such as growth, development, differentiation and cell, death by repressing their target genes, and in relation to cancer and some other diseases [52]. Some miRNAs are regulated by epigenetic mechanisms, especially by methylation [52]. Short interfering RNAs, are a class of double-strnded RNA (dsRNA) molecules, that can guide methylation to complementary DNA, were first elucidated in plants, to enable the precise targeting of gene action [164]. Plant-derived miRNAs which enter the blood stream have been shown to muffle or amplify gene expression by binding to strands of messenger RNA with potential for therapy [53].

DNAmn and metals. Epigenetics may be the critical pathway by which metals produce their health effects [108,165]. Copper [166-168], zinc [168] and selenium $[168,169]$ have each been linked to the pathogenesis of AIS. Other metals disrupt DNAm [170,171].

DNAm in MZ twins, aging and epigenetic drift. Recent studies using mostly peripheral blood lymphocytes (also skin, muscle and fat) and a battery of powerful molecular genetic methodologies coupled with competitive chromosomal hybridizations, suggest that phenotypic discordance between MZ twins is to some extent due to epigenetic factors that change over the lifetime of a multicellular organism $[24,99]$. It has been proposed that epigenetic drift during development can result from stochastic mechanisms (independent of environmental perturbations), or determined by such environmental perturbations $[24,99,172]$. Eckhardt et al [63] found no age-related DNAm change but did not report longitudinal data. In a longitudinal study, Bjornsson et al [14] found methylation changes over time with familial clustering suggesting that methylation maintenance may be under genetic control. In $46 \mathrm{MZ}$ twin-pairs and $45 \mathrm{DZ}$ twin-pairs Wong et al [50] found that DNAm differences are apparent already in early childhood, even between genetically identical individuals; and that individual differences in methylation are not stable over time. Unlike the primary DNA sequence, methylation status will depend on the tissue being analysed [Armour J personal communication]. Epigenetic mechanisms may be causal in the aging process and be influenced by diet providing opportunities to improve health in later life [108].

\section{APPENDIX VI}

In connection with epigenetic interactions in normal development, Lieberman [138] writes:

"In normal development, "... hormones and growth factors bind with specific receptors in the cell membrane or nucleus. Activated receptors then trigger a cellular response through mechanisms such as altering gene transcription, altering ion transport in and out of the cell, activating or inhibiting intracellular enzymes, stimulating protein synthesis, or inducing cellular proliferation."

"Regulation of local growth occurs through interactions between the genes that cause skeletogenic cells to synthesize, resorb, or otherwise modify skeletal tissue, and stimuli from other genes or cells. Such interaction between cells and their environment (which includes other cells) are generally categorized as epigenetic interactions... Additional categories of epigenetic interactions influencing morphogenesis include systemic hormones, growth factors, and the effects of mechanical loading."

"Bones do have a strong genetic component to their growth and development, but a set of complex and constrained interactions between bone cells and their mechanical environment can influence bone morphology, particularly while the skeleton is still growing." (see Herring [136] in Appendix IV]).

\section{APPENDIX VII}

Some hypotheses and concepts of AIS etiopathogenesis $[2,6,192]$

(1) Genetics [2,4,5,92,193-199].

(2) Biomechanical spinal growth modulation [181,182].

(3) Relative anterior spinal overgrowth (RASO) [200-203].

(4) Dorsal shear forces and axial rotation instability $[204,205]$.

(5) Asynchronous spinal neuro-osseous growth [206-211].

(6) Postural abnormalities including vestibular and CNS dysfunction [2,212,213].

(7) Motor control problem [214-217].

(8) Body-spatial orientation concept [218].

(9) Neurodevelopmental concept [219].

(10) Thoracospinal concept [79-83,220,221].

(11) Deforming three joint complex hypothesis [222].

(12) Systemic melatonin deficiency [223-226].

(13) Systemic melatonin-signaling pathway dysfunction [173,174,177,227-230].

(14) Relative osteopenia [113,114,231,232].

(15) Systemic platelet calmodulin dysfunction [233-236].

(16) Developmental instability \& symmetry control dysfunction [85-87,237-241].

(17) Intrinsic growth plate asymmetry hypothesis [74,75,188,237-241].

(18) Collective and escalator models [192].

(19) Leptin-hypothalamic-sympathetic nervous system (LHS) dysfunction with disharmony between somatic and autonomic nervous systems in the spine and trunk [[6], see $[3,242]]$. 


\section{Acknowledgements}

Dr Ruth Wynne-Davies helped to initiate this review at, and subsequent to, the 12th International Phillip Zorab Symposium in London on 16-18 March 2011. We are grateful to Professor J Armour, Professor of Human Genetics and Head, School of Biology, University of Nottingham, UK, for reading the text and making suggestions. Discussions with Mrs M E McMaster about her research provoked our early interest in epigenetics and we thank her for allowing us to quote from her recent paper [77], for reading the text and making suggestions. We thank Dr SS Upadhyay for reading the text and for suggestions, and Mr Lyndon Cochrane for the art work.

\section{Author details}

${ }^{1}$ Centre for Spinal Studies and Surgery, Nottingham University Hospitals Trust, Queen's Medical Centre Campus, Derby Road, Nottingham, NG7 2UH, UK. ${ }^{2}$ University of Liverpool, Ashton Street, L69 3GE, UK. ${ }^{3}$ Staffordshire University, Leek Road, Stoke-on-Trent, ST4 2DF. UK. ${ }^{4}$ Royal Liverpool Children's Hospital, Eaton Road, Liverpool, L12 2AP, UK. ${ }^{5}$ Department of Orthopaedic Surgery, King's Mill Hospital, Sutton Road, Mansfield NG17 4JL, UK. 'Department of Trauma and Orthopedics, "Tzanio" General Hospital, Tzani and Afendouli 1 st, Piraeus 18536, Greece.

\section{Authors' contributions}

GB with TG, PD and AM initiated this review at the time of presentations in London [240] and Padua [76]. GB wrote the text and conceived the novel concepts relating to the exposome and spinal development in health and AIS. PD and TG helped GB in finding and obtaining references. All authors contributed their professional skills to the ensuing discussions as the text and Figures progressed. All authors have read and approved the final manuscript.

\section{Competing interests}

The authors declare that they have no competing interests.

Received: 10 October 2011 Accepted: 2 December 2011 Published: 2 December 2011

\section{References}

1. Butcher $L M$, Beck S: Future impact of integrated high-throughput methylome analyses on human health and disease. J Genet Genomics 2008, 35(7):391-401.

2. Wang WJ, Yeung HY, Chu WC, Tang NL, Lee KM, Qiu Y, Burwell RG, Cheng JC: Top theories for the etiopathogenesis of adolescent idiopathic scoliosis. J Pediatr Orthop 2011, 31(1 Suppl):S14-27.

3. Lombardi G, Akoume MY, Colombini A, Moreau A, Banfi G: Biochemistry of adolescent idiopathic scoliosis. Adv Clin Chem 2011, 54:165-82.

4. Fendri K, Patten S, Zaouter C, Parent S, Kaufman G, Labelle H, Edery P, Moldovan F: Recent advances in the study of candidate genes for adolescent idiopathic scoliosis. Stud Health Technol Inform 2010, 158:3-7.

5. Edery P, Margaritte-Jeannin P, Biot B, Labalme A, Bernard JC, Chastang J, Kassai B, Plais MH, Moldovan F, Clerget-Darpoux : New disease gene location and high genetic heterogeneity in idiopathic scoliosis. Eur $J$ Hum Genet 2011, 19(8):865-9.

6. Burwell RG, Aujla RK, Grevitt MP, Dangerfield PH, Moulton A, Randell TL, Anderson SI: Pathogenesis of adolescent idiopathic scoliosis in girls - a double neuro-osseous theory involving disharmony between two nervous systems, somatic and autonomic expressed in the spine and trunk: possible dependency on sympathetic nervous system and hormones with implications for medical therapy. Scoliosis 2009, 4:24

7. Barker DJ, Hales CN, Fall CH, Osmond C, Phipps K, Clark PM: Type 2 (noninsulin-dependent) diabetes mellitus, hypertension and hyperlipidaemia (syndrome X): relation to reduced fetal growth. Diabetologia 1993, 36(1):62-7.

8. Barker DJ, Eriksson JG, Forsén T, Osmond C: Fetal origins of adult disease: strength of effects and biological basis. Int J Epidemiol 2002, 31(6):1235-9.

9. Gluckman PD, Hanson MA: The developmental origins of health and disease: an overview. In Developmental mechanisms of health and disease Volume 1. Edited by: Gluckman P, Hanson M. Cambridge: Cambridge University Press; 2006:1-5.

10. Gluckman PD, Hanson MA, Cooper C, Thornburg KL: Effect of in utero and early-life conditions on adult health and disease. N Engl J Med 2008, 359(1):61-73.
11. Gluckman PD, Hanson MA, Mitchell MD: Developmental origins of health and disease: reducing the burden of chronic disease in the next generation. Genome Med 2010, 24, 2(2):14.

12. Gluckman PD, Hanson MA, Beedle AS, Buklijas T, Low FM: Epigenetics of human disease. In Epigenetics linking genotype and phenotype in development and evolution. Volume 22. Edited by: Hallgrimsson B, Hall BK. Berkeley: University of California Press; 2011:198-423.

13. Hochberg Z, Feil R, Constancia M, Fraga M, Junien C, Carel JC, Boileau P, Le Bouc Y, Deal CL, Lillycrop K, Scharfmann R, Sheppard A, Skinner M, Szyf M, Waterland RA, Waxman DJ, Whitelaw E, Ong K, Albertsson-Wikland K: Child health, developmental plasticity, and epigenetic programming. Endocr Rev 2011, 32(2):159-224.

14. Bjornsson HT, Fallin MD, Feinberg AP: An integrated epigenetic and genetic approach to common human disease. Trends Genet 2004, 20(8):350-8.

15. Bjornsson HT, Cui H, Gius D, Fallin MD, Feinberg AP: The new field of epigenomics: implications for cancer and other common disease research. Cold Spring Harb Symp Quant Biol 2004, 69:447-56.

16. Feinberg AP: Phenotypic plasticity and the epigenetics of human disease. Nature 2007, 447(7143):433-40.

17. Feinberg AP: Epigenetics at the epicenter of modern medicine. JAMA 2008, 299(11):1345-50.

18. Feinberg AP: Genome-scale approaches to the epigenetics of common human disease. Virchows Arch 2010, 456(1):13-21.

19. Rappaport SM, Smith MT: Epidemiology. Environment and disease risks. Science 2010, 330(6003):460-1.

20. Hanson MA, Low FM, Gluckman PD: Epigenetic epidemiology: the rebirth of soft inheritance. Ann Nutr Metab 2011, 58(Suppl 2):8-15.

21. Reardon S: A world of chronic disease. Science 2011, 333(6042):558-9.

22. Reardon S: U.N. Summit on noncommunicable diseases. Meeting brings attention but little action on chronic diseases. Science 2011, 333(6049):1561.

23. Russo VEA, Martienssen RA, Riggs AD, (Eds): Epigenetic mechanisms of gene regulation. Monograph 32 Cold Spring Harbor Laboratory Press, Cold Spring Harbor, New York, USA; 1996, 692.

24. Fraga MF, Ballestar E, Paz MF, Ropero S, Setien F, Ballestar ML, HeineSuñer D, Cigudosa JC, Urioste M, Benitez J, Boix-Chornet M, SanchezAguilera A, Ling C, Carlsson E, Poulsen P, Vaag A, Stephan Z, Spector TD, Wu YZ, Plass C, Esteller M: Epigenetic differences arise during the lifetime of monozygotic twins. Proc Natl Acad Sci USA 2005, 102(30):10604-9.

25. Bird A: Perceptions of epigenetics. Nature 2007, 447(7143):396-8.

26. Suzuki MM, Bird A: DNA methylation landscapes: provocative insights from epigenomics. Nat Rev Genet 2008, 9(6):465-76.

27. Whitelaw E, Garrick D: Epigenetic mechanisms. In Developmental mechanisms of health and disease. Volume 5. Edited by: Hallgrimsson B, Hall BK. Cambridge University Press; 2006:62-74.

28. Rivera RM, Bennett LB: Epigenetics in humans: an overview. Curr Opin Endocrinol Diabetes Obes 2010, 7(6):493-9.

29. Nelissen EC, van Montfoort AP, Dumoulin JC, Evers JL: Epigenetics and the placenta. Hum Reprod Update 2011, 17(3):397-417.

30. Lipps HJ, Postberg J, Jackson DA, (Eds.): Epigenetics, disease and behavior. Essays in Biochemistry 2010, 48:292.

31. Carey N: The epigenetics revolution. Icon Books: London; 2011, 339.

32. Francis RC: Epigenetics, the ultimate mystery of inheritance. New York: WW Norton \& Company; 2011, 234.

33. Strauss A: Dietray recommendations for idiopathic scoliosis., www.

34. Dovorany BT, Stitzel CJ: Scoliosis - treatment and epigenetics., www.

35. Bogin B: Environmental factors influencing growth. In Patterns of human growth. Volume 6.. Second edition. Cambridge: Cambridge: University Press; 1999:268-328.

36. Bogin B: The growth of humanity. New York, A John Wiley \& Sons Inc. Publication; 2001, 19.

37. Dasgupta P, Hauspie R, (Eds): Perspectives in human growth, development and maturation Dordrecht:Kluwer Academic publishers; 2001, 364.

38. Schell LM, Gallo MV, Ravenscroft J: Environmental influences on human growth and development: historical review and case study of contemporary influences. Ann Hum Biol 2009, 36(5):459-77.

39. Bogin B, Varela-Silva MI: Leg length, body proportion, and health: a review with a note on beauty. Int J Environ Res Public Health 2010, 7(3):1047-75. 
40. Green J, Cairns BJ, Casabonne D, Wright FL, Reeves G, Beral V: Height and cancer incidence in the Million Women Study: prospective cohort, and meta-analysis of prospective studies of height and total cancer risk. Lancet Oncol 2011, 12(8):785-94.

41. Caspi A, Williams B, Kim-Cohen J, Craig IW, Milne BJ, Poulton R, Schalkwyk LC, Taylor A, Werts H, Moffitt TE: Moderation of breastfeeding effects on the IQ by genetic variation in fatty acid metabolism. Proc Natl Acad Sci USA 2007, 104(47):18860-5.

42. Plomin R, DeFries JC, McClearn GE, McGuffin P: The interplay between genes and environment. In Behavioral genetics. Volume 16.. Fifth edition. New York: Worth Publishers; 2008:305-333.

43. Lester BM, Tronick E, Nestler E, Abel T, Kosofsky B, Kuzawa CW, Marsit CJ, Maze I, Meaney MJ, Monteggia LM, Reul JM, Skuse DH, Sweatt JD, Wood MA: Behavioral epigenetics. Ann N Y Acad Sci 2011, 226:14-33.

44. Heijmans BT, Tobi EW, Lumey LH, Slagboom PE: The epigenome: archive of the prenatal environment. Epigenetics 2009, 4(8):526-31.

45. Szyf M: The early life social environment and DNA methylation; DNA methylation mediating the long-term impact of social environments early in life. Epigenetics 2011.

46. Hamilton JP: Epigenetics: principles and practice. Dig Dis 2011, 9(2):130-5.

47. Maloy KJ, Powrie F: Intestinal homeostasis and its breakdown in inflammatory bowel disease. Nature 2011, 474(7351):298-306.

48. Waterland RA: Epigenetic mechanisms and gastrointestinal development. J Pediatr 2006, 149(5 Suppl):S137-42.

49. Engesaeter LB: Increasing incidence of club foot: changes in the genes or the environment? Acta Orthop 2006, 77(6):837-838.

50. Wong CC, Caspi A, Williams B, Craig IW, Houts R, Ambler A, Moffitt TE, Mill J: A longitudinal study of epigenetic variation in twins. Epigenetics 2010, 5(6):516-26.

51. Csaba G: The biological basis and clinical significance of hormonal imprinting, an epigenetic process. Clin Epigenetics 2011, 2:187-196.

52. Silahtaroglu A, Stenvang J: MicroRNAs, epigenetics and disease. Essays Biochem 2010, 48(1):165-85

53. Jabr E: Eating genes alters genes. New Sci 2011, 211(2832):10-11

54. Lister R, Pelizzola M, Dowen RH, Hawkins RD, Hon G, Tonti-Filippini J, Nery JR, Lee L, Ye Z, Ngo QM, Edsall L, Antosiewicz-Bourget J, Stewart R, Ruotti V, Millar AH, Thomson JA, Ren B, Ecker JR: Human DNA methylomes at base resolution show widespread epigenomic differences. Nature 2009, 462(7271):315-22.

55. Cropley JE, Martin DI, Suter CM: Germline epimutation in humans. Pharmacogenomics 2008, 9(12):1861-8.

56. Reik W: Stability and flexibility of epigenetic gene regulation in mammalian development. Nature 2007, 447(7143):425-32.

57. Feng S, Jacobsen SE, Reik W: Epigenetic reprogramming in plant and animal development. Science 2010, 330(6004):622-7.

58. Holliday R: Dual inheritance. Curr Top Microbiol Immunol 2006, 301:243-56.

59. Martin DI, Cropley JE, Suter CM: Epigenetics in disease: leader or follower? Epigenetics 2011, 6(7):843-8

60. Greene ND, Stanier P, Moore GE: The emerging role of epigenetic mechanisms in the etiology of neural tube defects. Epigenetics 2011, 6(7):875-83.

61. Jessen HM, Auger AP: Sex differences in epigenetic mechanisms may underlie risk and resilience for mental health disorders. Epigenetics 2011, 6(7):857-61.

62. Bradbury J: Human Epigenome Project-up and running. PLOS Biol 2003, 1(3):e82..

63. Eckhardt F, Lewin J, Cortese R, Rakyan VK, Attwood J, Burger M, Burton J, Cox TV, Davies R, Down TA, Haefliger C, Horton R, Howe K, Jackson DK, Kunde J, Koenig C, Liddle J, Niblett D, Otto T, Pettett R, Seemann S, Thompson C, West T, Rogers J, Olek A, Berlin K, Beck S: DNA methylation profiling of human chromosomes 6, 20 and 22. Nat Genet 2006, 8(12):1378-85

64. American Association for Cancer Research Human Epigenome Task Force, European Union, Network of Excellence, Scientific Advisory Board: Moving AHEAD with an international human epigenome project. Nature 2008, 454(7205):711-5

65. Annotation: Time for the epigenome. Nature 2010, 463(7281):587.

66. Ptashne $\mathrm{M}$, Hobert $\mathrm{O}$, Davidson $\mathrm{E}$ : Questions over the scientific basis of epigenome project. Nature 2010, 464(7288):487.

67. Franz-Odendaal TA: Epigenetics in bone and cartilage development. In Epigenetics linking genotype and phenotype in development and evolution.
Volume 12. Edited by: Hallgrimsson B, Hall BK. Berkeley: University of California Press; 2011:195-220.

68. Herring SW: Muscle-bone interactions and the development of skeletal phenotype. In Epigenetics linking genotype and phenotype in development and evolution. Volume 13. Edited by: Hallgrimsson B, Hall BK. Berkeley: University of California Press; 20110:221-237

69. O'Connor RD, Schanan NC: Genetic and epigenetic aspects of bone development. In Bone and Development. Volume 6. Edited by: Bronner F MCFarach-Carson, HI Roach. Springer London, Topics in Bone Biology; 2010:1-23, Chapter 1

70. Percival C, Richtsmeier JT: The epigenetics of dysmorphology. In Epigenetics linking genotype and phenotype in development and evolution Volume 21. Edited by: Hallgrimsson B, Hall BK. Berkeley: University of California Press; 2010:377-397.

71. Cassidy SB, Schwartz S, Miller JL, Driscoll DJ: Prader-Willi syndrome. Genet Med 2011

72. Carey N: The battle of the sexes, when imprinting goes bad. In The epigenetics revolution. Volume 8. Edited by: Carey N. London: Icon Books; 2011:136-139.

73. Burwell RG, Aujla RK, Cole AA, Randell TL, Dangerfield PH, Moulton A: Length asymmetries in upper limbs of right- and left-handed healthy girls age 5-18 years: proximo-distal reciprocal linear growth asynchronies, genetics, handedness and epigenetics [abstract]. Clin Anat 2011, 24(4):529-530.

74. Burwell RG, Aujla RK, Randell TL, Dangerfield PH, Moulton A, Anderson SI: Regional skeletal sizes of healthy girls relative to size attained at 10 years as the comparator: percentage size trajectories reveal effects of differential growth consistent with intrinsic growth-plate programs involving time-tally patterning, genetically- and epigeneticallydetermined [abstract]. Proceedings of the Summer Meeting of the British Association of Clinical Anatomists, Padua, Italy, 29th June to 1st July 2011. Clin Anat

75. Burwell RG, Aujla RK, Randell TL, Dangerfield PH, Moulton A, Anderson SI: Regional skeletal sizes of healthy boys relative to size attained at 10 years as the comparator: percentage size trajectories reveal effects of differential growth consistent with intrinsic growth-plate programs involving time-tally patterning, genetically- and epigeneticallydetermined [abstract]. Proceedings of the Summer Meeting of the British Association of Clinical Anatomists, Padua, Italy, 29th June to 1st July 2011; Clin Anat

76. Burwell RG, Grevitt MP, Aujla RK, Randell TL, Dangerfield PH, Aujla RK Cole AA, Pratt RK, Webb JK, Moulton A, Anderson SI: Abnormal bilateral skeletal asymmetries and their putative genetic and epigenetic origins in enantiomorphic growth plates of girls with adolescent idiopathic scoliosis (AIS) [abstract]. Proceedings of the Summer Meeting of the British Association of Clinical Anatomists, Padua, Italy, 29th June to 1st July 2011; Clin Anat

77. McMaster ME: Heated indoor swimming pools, infants, and the pathogenesis of adolescent idiopathic scoliosis: a neurogenic hypothesis. Environ Health

78. Frazer KA, Murray SS, Schork NJ, Topol EJ: Human genetic variation and its contribution to complex traits. Nat Rev Genet 2009, 10(4):241-51.

79. Sevastik J: The "thoracospinal" concept of the early development of idiopathic scoliosis. Experimental and clinical considerations. In International Symposium on 3-D Scoliotic Deformities joined with the VIIth International Symposium on Spinal Deformity and Surface Topography. Edited by: Dansereau J. Ėdition de l'École Polytechnique de Montrēal:Gustav Fischer Verlag; 1992:193-7.

80. Sevastik B, Xiong B, Lundberg A, Sevastik JA: In vitro opto-electronic analysis of 3-D segmental vertebral movements during gradual rib lengthening in the pig. Acta Orthop Belg 1995, 61(3):218-25.

81. Sevastik JA: The thoracospinal concept of the etiopathogenesis of idiopathic scoliosis. In Etiology of Adolescent Idiopathic Scoliosis: Current Trends and Relevance to New Treatment Approaches. Volume 14. Edited by: Burwell RG, Dangerfield PH, Lowe TG, Margulies JY. State of the Art Reviews: Spine; 2000:(2):391-400

82. Sevastik JA: Dysfunction of the autonomic nerve system (ANS) in the aetiopathogenesis of adolescent idiopathic scoliosis. Stud Health Technol Inform 2002, 88:20-3.

83. Sevastik J, Burwell RG, Dangerfield PH: A new concept for the etiopathogenesis of the thoracospinal deformity of idiopathic scoliosis: 
summary of an electronic focus group debate of the IBSE. Eur Spine 2003, 12:440-50

84. Wynne-Davies R, Littlejohn A, Gormley J: Aetiology and interrelationship of some common skeletal deformities. (Talipes equinovarus and calcaneovalgus, metatarsus varus, congenital dislocation of the hip, and infantile idiopathic scoliosis). J Med Genet 1982, 19(5):321-8.

85. Goldberg CJ, Dowling FE, Fogarty EE, Moore DP: Adolescent idiopathic scoliosis as developmental instability. Genetica 1995, 96(3):247-55.

86. Goldberg CJ, Fogarty EE, Moore DP, Dowling FE: Scoliosis and developmental theory: adolescent idiopathic scoliosis. Spine 1997, 22(19):2228-37.

87. Goldberg CJ: Symmetry control. In Etiology of Adolescent Idiopathic Scoliosis: Current Trends and Relevance to New Treatment Approaches, State of the Art Reviews: Spine. Volume 14. Edited by: Burwell RG, Dangerfield PH, Lowe TG, Margulies JY. Philadelphia, Hanley 2000:(2):327-8.

88. Kesling KL, Reinker KA: Scoliosis in twins. A meta-analysis of the literature and report of six cases. Spine (Phila Pa 1976) 1997, 22(17):2009-14, discussion 2015.

89. Wynne-Davies R: Familial (idiopathic) scoliosis. A family survey. J Bone Joint Surg Br 1968, 50(1):24-30.

90. Sales de Gauzy J, Ballouhey Q, Arnaud C, Grandjean H, Accadbled F: Concordance for curve type in familial idiopathic scoliosis: a survey of one hundred families. Spine (Phila Pa 1976) 2010, 35(17):1602-6.

91. Inoue M, Minami S, Kitahara H, Otsuka Y, Nakata Y, Takaso M, Moriya H: Idiopathic scoliosis in twins studied by DNA fingerprinting: the incidence and type of scoliosis. J Bone Joint Surg Br 1998, 80(2):212-7.

92. Miller NH: Genetics of familial idiopathic scoliosis. Clin Orthop Rel Res 2007, 462:6-10.

93. Andersen $\mathrm{MO}$, Thomsen $\mathrm{K}$, Kyvik KO: Adolescent idiopathic scoliosis in twins: a population-based survey. Spine (Phila Pa 1976) 2007, 32(8):927-30.

94. Grauers A, Rahman I, Gerdhem P: Heritability of scoliosis in the Swedish Twin Registry. Stud Health Technol Inform 2010, 158:194.

95. van Rhijn LW, Jansen EJ, Plasmans CM, Veraart BE: Curve characteristics in monozygotic twins with adolescent idiopathic scoliosis: 3 new twin pairs and a review of the literature. Acta Orthop Scand 2001, 72(6):621-5.

96. Smyrnis T, Antoniou D, Valavanis J, Zachariou C: Idiopathic scoliosis: characteristics and epidemiology. Orthopedics 1987, 10(6):921-6.

97. Hermus JP, van Rhijn LW, van Ooij A: Non-genetic expression of adolescent idiopathic scoliosis: a case report and review of the literature. Eur Spine J 2007, 16(Suppl 3):338-41.

98. Kaspiris A, Grivas TB, Weiss HR: Congenital scoliosis in monozygotic twins: case report and review of possible factors contributing to its development. Scoliosis 2008, 18;3:17.

99. Martin GM: Epigenetic drift in aging identical twins. Proc Natl Acad SCi USA 2005, 102(30):10413-4.

100. Day JJ, Sweatt JD: Epigenetic mechanisms in cognition. Neuron 2011, 70(5):813-29.

101. Golding J: Observations on idiopathic scoliosis: aetiology and natural history in Jamaica - a food and growth connection. Cajanus 1991, 24(1):31-38

102. Worthington $V$, Shambaugh P: Nutrition as an environmental factor in the etiology of idiopathic scoliosis. J Manipulative Physiol Ther 1993, 16(3):169-73.

103. Enwonwu CO, Sanders C: Nutrition: impact on oral and systemic health Compend Contin Educ Dent 2001, 22(3 Spec No):12-8.

104. Park LK, Friso S, Choi SW: Nutritional influences on epigenetics and agerelated disease. Proc Nutr Soc 2011

105. Carey N: The sins of the fathers. In The epigenetics revolution. Volume 6. Edited by: Carey N. London: Icon Books; 2011:97-114.

106. Feil R: Epigenetics: Ready for the marks. Nature 2009, 461(7262):359-60.

107. Kaati G, Bygren LO, Pembrey M, Sjöström M: Transgenerational response to nutrition, early life circumstances and longevity. Eur J Hum Genet 2007, 15(7):784-90.

108. Ford $D$, lons $L$, Alatawi F, Wakeling LA: The potential role of epigenetic responses to diet in ageing. Proc Nutr Soc 2011, 70(3):374-84.

109. Francis RC: A grandmother effect. In Epigenetics, the ultimate mystery of inheritance. Volume 1. New York: WW Norton \& Company; 2011:1-8.

110. Van den Veyver IB: Genetic effects of methylation diets. Annu Rev Nutr 2002, 22:255-82.

111. Burwell RG: Aetiology of idiopathic scoliosis: current concepts. Pediatr Rehabil 2003, 6(3-4):137-70.
112. Burwell RG, Dangerfield PH: Hypotheses on the pathogenesis of adolescent idiopathic scoliosis (AIS): a neurodevelopmental concept involving neuronal lipid peroidation and possible prevention by diet. In International Research Society of Spinal Deformities Symposium Edited by: Bonita J Sawatzky, Vancouver 2004, 34-38.

113. Hung WWY, Qin L, Cheung CSK, Lam TP, Ng BKW, Tse YK, Go X, Lee KM, Cheng JCY: Osteopenia: a new prognostic factor of curve progression in adolescent idiopathic scoliosis. J Bone Joint Surg Am 2005, 87-A:2709-2716.

114. Lam TP, Hung WW, Yeung HY, Tse YK, Chu WC, Ng BK, Lee KM, Qin L, Cheng JC: Abnormal bone quality in adolescent idiopathic scoliosis: a case-control study on 635 subjects and 269 normal controls with bone densitometry and quantitative ultrasound. Spine (Phila Pa 1976) 2011, 36(15):1211-7.

115. McMaster M, Lee AJ, Burwell RG: Physical activities of patients with adolescent idiopathic scoliosis (AIS) compared with a control group: implications for etiology and possible prevention. In International Research Society of Spinal Deformities Symposium Edited by: Bonita J Sawatzky, Vancouver 2004, 68-71.

116. McMaster M, Lee AJ, Burwell RG: Physical activities of patients with adolescent idiopathic scoliosis (AIS) compared with a control group: implications for etiology and possible prevention [abstract]. J Bone Joint Surg Br 2006, 88-B(Supp II):225.

117. Bagnall KM: Ligaments and muscles in adolescent idiopathic scoliosis. In Etiology of Adolescent Idiopathic Scoliosis: Current Trends and Relevance to New Treatment Approaches, State of the Art Reviews: Spine. Volume 14. Edited by: Burwell RG, Dangerfield PH, Lowe TG, Margulies JY. Philadelphia, Hanley 2000:(2):447-57.

118. Grivas TB, Vasiliadis E, Mouzakis V, Mihas C, Koufopoulos G: Association between adolescent idiopathic scoliosis prevalence and age at menarche in different geographic latitudes. Scoliosis 2006, 23, 1:9.

119. De George FV, Fisher RL: Idiopathic scoliosis: genetic and environmental aspects. J Med Genet 1967, 4(4):251-7.

120. James JIP, Wynne-Davies R: Genetic factors in Orthopaedics. In Recent Advances in Orthopaedics. Volume 1. Edited by: Apley AG. London; J 1969:1-35.

121. Ryan MD, Nachemson A: Thoracic adolescent idiopathic scoliosis: perinatal and environmental aspects in a Swedish population and their relationship to curve severity. J Pediatr Orthop 1987, 7(1):72-7.

122. McMaster M, Lee AJ, Burwell RG: Indoor heated swimming pools: vulnerability of some infants to develop spinal asymmetries years later. Stud Health Technol Inform 2006, 123:151-155.

123. Burwell RG, Dangerfield PH, Vernon CL: Anthropometry and scoliosis. In Scoliosis, Proceedings of a Fifth Symposium. Edited by: Zorab PA. London: Academic Press; 1977:123-163.

124. Burwell RG, Dangerfield PH, James NJ, Johnson F, Webb JK, Wilson YG Anthropometric studies of normal and scoliotic children: axial and appendicular skeletal asymmetry, sexual dimorphisms and age-related changes. In Pathogenesis of idiopathic scoliosis. Proceedings of an international conference. Edited by: Jacobs RR. Chicago: Scoliosis Research Society; 1984:27-44.

125. Goldstein DB: Growth of genome screening needs debate. Nature 2011, 476(7358):27-8.

126. Hamzelou J: Welcome to the exposome. New Sci 2011, 208(2792/ 2793):6-7.

127. Wild CP: Complementing the genome with an "exposome": the outstanding challenge of environmental exposure measurement in molecular epidemiology. Cancer Epidemiol Biomarkers Prev 2005, 14(8):1847-50.

128. Faisandier L, Bonneterre V, De Gaudemaris R, Bicout DJ: Occupational exposome: A network-based approach for characterizing Occupational Health Problems. J Biomed Inform 2011, 44(4):545-52.

129. Krzywanski DM, Moellering DR, Fetterman JL, Dunham-Snary KJ, Sammy MJ, Ballinger SW: The mitochondrial paradigm for cardiovascular disease susceptibility and cellular function: a complementary concept to Mendelian genetics. Lab Invest 2011, 91(8):1122-35.

130. Dunn R: The wild life of our bodies: predators, parasites, and partners that shape who we are today. New York: Harper Collins Publishers; 2010, 290.

131. Waddington CH: The epigenotype. Endeavour 1942, 1:18-20.

132. Nanney DL: Epigenetic control systems. Proc Natl Acad Sci USA 1958, 44(7):712-7. 
133. Haig D: The (dual) origin of epigenetics. Cold Spring Harb Symp Quant Biol 2004, 69:67-70

134. Holliday R: Epigenetics: a historical overview. Epigenetics 2006, 1(2):76-80.

135. Riggs AD, Martienssen RA, Russo VEA: Introduction. In Epigenetic mechanisms of gene regulation, Monograph 32. Edited by: Russo VEA, Martienssen RA, Riggs AD. Cold Spring Harbor Laboratory Press, Cold Spring Harbor, New York, USA; 1996:1-4.

136. Herring SW: Formation of the vertebrate face; epigenetic and functional influences. Amer Zoo 1993, 33:472-483.

137. Herring SW: Muscle-bone interactions and the development of the skeletal phenotype: jaw muscles and the skull. In Epigenetics linking genotype and phenotype in development and evolution. Volume 13. Edited by: B Hallgrimsson B, Hall BK. Berkeley: University of California Press; 2011:221-237.

138. Lieberman DE: The skeletal tissues of the head. In The evolution of the human head. Volume 2. Cambridge Massachusetts: The Belknap Press of Harvard University Press; 2011:18-55.

139. Lieberman DE: Epigenetic integration, complexity, and evolvability of the head. In Epigenetics linking genotype and phenotype in development and evolution. Volume 16. Edited by: Hallgrimsson B, Hall BK. Berkeley: University of California Press; 2011:271-289.

140. Jamniczky HA, Boughner JC, Rolian C, Gonzalez PN, Powell CD, Schmidt EJ, Parsons TE, Bookstein FL, Hallgrímsson B: Rediscovering Waddington in the post-genomic age: Operationalising Waddington's epigenetics reveals new ways to investigate the generation and modulation of phenotypic variation. Bioessays 2010, 32(7):553-8.

141. Bonasio R, Tu S, Reinberg D: Molecular signals of epigenetic states. Science 2010, 330(6004):612-6.

142. Chen ZX, Riggs AD: DNA methylation and demethylation in mammals. Biol Chem 2011, 286(21):18347-53

143. Tajerian M, Alvarado S, Millecamps M, Dashwood T, Anderson KM, Haglund L, Ouellet J, Szyf M, Stone LS: DNA methylation of SPARC and chronic low back pain. Mol Pain 2011, 7(1):65.

144. Holliday R: The inheritance of epigenetic defects. Science 1987, 238(4824):163-70.

145. Katsnelson A: Epigenome effort makes its mark. Nature 2010, 467(7316):646

146. Jeltsch A: Molecular biology. Phylogeny of methylomes. Science 2010, 328(5980):837-8

147. Murrell A, Rakyan VK, Beck S: From genome to epigenome. Hum Mol Genet 2005, 14 Spec No 1:R3-R10.

148. Riddihough G, Zahn LM: Epigenetics. What is epigenetics? Introduction. Science 2010, 330(6004):611.

149. Hallgrimsson B, Hall BK: Epigenetics: the context of development. In Epigenetics linking genotype and phenotype in development and evolution. Volume 23. Edited by: B Hallgrimsson B, Hall BK. Berkeley: University of California Press; 2011:424-438.

150. Waddington CH: Organisers and genes Cambridge: University Press; 1940, 160.

151. Francis RC: Sea urchins are not just to eat. In Epigenetics, the ultimate mystery of inheritance. Volume 10. New York: WW Norton \& Company; 2011:119-137.

152. Burwell RG, Dangerfield PH: Hypotheses on the pathogenesis of adolescent idiopathic scoliosis (AIS): X-chromosome mosaicism and microchimerism - need for appraisal in AIS? In International Research Society of Spinal Deformities Symposium Edited by: Bonita J Sawatzky, Vancouver 2004, 345-8.

153. Basu R, Zhang LF: X chromosome inactivation: A silence that needs to be broken. Genesis 2011.

154. Moreira de Mello JC, de Araújo ES, Stabellini R, Fraga AM, de Souza JE, Sumita DR, Camargo AA, Pereira LV: Random X inactivation and extensive mosaicism in human placenta revealed by analysis of allele-specific gene expression along the X chromosome. PLoS One 2010, , 6: e10947.

155. Henckel A, Nakabayashi K, Sanz LA, Feil R, Hata K, Arnaud P: Histone methylation is mechanistically linked to DNA methylation at imprinting control regions in mammals. Hum Mol Genet 2009, 18(18):3375-83.

156. Hirasawa R, Feil R: Genomic imprinting and human disease. Essays Biochem 2010, 8(1):187-200

157. Kouzarides T: Chromatin modifications and their function. Cell 2007, 128(4):693-705.
158. Bannister AJ, Kouzarides T: Regulation of chromatin by histone modifications. Cell Res 2011, 21(3):381-95.

159. Putiri EL, Robertson KD: Epigenetic mechanisms and genome stability. Clin Epigenetics 2011, 2(2):299-314.

160. Venkitaraman AR: Cancer: Let sleeping DNA lie. Nature 2011, 477(7363):169-70.

161. Schübeler D: Epigenomics: Methylation matters. Nature 2009, 462(7271):296-7

162. Kinney SM, Chin HG, Vaisvila R, Bitinaite J, Zheng Y, Estève PO, Feng S, Stroud H, Jacobsen SE, Pradhan S: Tissue-specific distribution and dynamic changes of 5-hydroxymethylcytosine in mammalian genomes. J Biol Chem 2011, 286(28):24685-93.

163. Ingrosso D, Perna AF: Epigenetics in hyperhomocysteinemic states. A special focus on uremia. Biochim Biophys Acta 2009, 790(9):892-9.

164. Waterland RA: Does nutrition during infancy and early childhood contribute to later obesity via metabolic imprinting of epigenetic gene regulatory mechanisms? Nestle Nutr Workshop Ser Pediatr Program 200, 56:157-71, discussion 171-4

165. Wrobel K, Wrobel K, Caruso JA: Epigenetics: an important challenge for ICP-MS in metallomics studies. Anal Bioanal Chem 2009, 393(2):481-6.

166. Pratt WB, Phippen WG: Elevated hair copper level in idiopathic scoliosis: preliminary observations. Spine (Phila Pa 1976) 1980, 5(3):230-3.

167. Pratt WB, Schader JB, Phippen WG: Elevation of hair copper in idiopathic scoliosis. A follow-up report. Spine (Phila Pa 1976) 1984, 9(5):540.

168. Dastych M, Cienciala J, Krbec M: Changes of selenium, copper, and zinc content in hair and serum of patients with idiopathic scoliosis. J Orthop Res 2008, 26(9):1279-82.

169. Yang Z, Xie Y, Chen J, Zhang D, Yang C, Li M: High selenium may be a risk factor of adolescent idiopathic scoliosis. Med Hypotheses 2010, 75(1):126-7.

170. Poirier $L A$, Vlasova TI: The prospective role of abnormal methyl metabolism in cadmium toxicity. Environ Health Perspect 2002, 110(Suppl 5):793-5.

171. Sutherland JE, Costa M: Epigenetics and the environment. Ann N Y Acad Sci 2003, 983:151-60

172. Poulsen $P$, Esteller M, Vaag A, Fraga MF: The epigenetic basis of twin discordance in age-related diseases. Pediatr Res 2007, 61(5 Pt 2):38R-42R.

173. Azeddine B, Franco A, Rompré PH, Roy-Gagnon M-H, Turgeon I, Boiro MS, Blain S, Boulanger H, Wang DS, Bagnall KM, Poitras B, Labelle HLL, Rivard CH, Grimard G, Ouellet J, Parent S, Moreau A: High circulating levels of osteopontin are associated with idiopathic scoliosis onset and spinal deform.ity progression. Proceedings of Pediatric Orthopaedic Society of North America 25th Anniversary 2009 Annual Meeting Boston, Massachusetts Boston Marriott Copley Place; 2009, 128, In Scoliosis Research Society 44th Annual Meeting and Course, San Antonio, Texas, USA, September 23-26, 200;109, and Stud Health Technol Inform. 2010, 158:207.

174. Moreau A, Akoumé Ndong MY, Azeddine B, Franco A, Rompré PH, RoyGagnon MH, Turgeon I, Wang D, Bagnall KM, Poitras B, Labelle H, Rivard CH, Grimard G, Ouellet J, Parent S, Moldovan F: Molecular and genetic aspects of idiopathic scoliosis: Blood test for idiopathic scoliosis. Orthopade 2009, 38(2):114-21, (German).

175. Fendri K, Moldovan F: Potential role of COMP as a biomarker for adolescent idiopathic scoliosis. Med Hypotheses 2011, 76(5):762-3.

176. Anderson HC, Shapiro L: The epiphyseal growth plate. In Bone and Development. Volume 6. Edited by: Bronner F, MCFarach-Carson, Roach HI. Springer London, Topics in Bone Biology; 2010:39-64, Chapter 3.

177. Azeddine B, Letellier K, Wang DS, Moldovan F, Moreau A: Molecular determinants of melatonin signaling dysfunction in adolescent idiopathic scoliosis. Clin Orthop Rel Res 2007, 462:45-52.

178. Hofman BD, Grashoff C, Schwartz MA: Dynamic molecular processes mediate cellular mechanotransduction. Nature 2011, 475(7356):316-23.

179. Villemure I, Stokes IA: Growth plate mechanics and mechanobiology. A survey of present understanding. J Biomech 2009, 42(12):1793-803.

180. Rajasekaran S, Natarajan RN, Babu JN, Kanna PR, Shetty AP, Andersson GB: Lumbar Vertebral Growth is governed by 'Chondral Growth Force Response Curve' rather than 'Hueter-Volkmann Law': A ClinicoBiomechanical Study of Growth Modulation Changes in Childhood Spinal Tuberculosis. Spine (Phila Pa 1976) 2011.

181. Stokes IAF, Burwell RG, Dangerfield PH: Biomechanical spinal growth modulation and progressive adolescent scoliosis - a test of the 'vicious 
cycle' pathogenetic hypothesis: Summary of an electronic focus group debate of the IBSE. Scoliosis 2006, 1:16.

182. Stokes IAF: Analysis and simulation of progressive adolescent scoliosis by biomechanical growth modulation. Eur Spine J 2007, 16:1621-8.

183. Rizzo-Sierra CV, Leon-Sarmiento FE: Pathophysiology of movement disorders due to gravity transitions: the channelopathy linkage in human balance and locomotion. Med Hypotheses 2011, 77(1):97-100

184. Xiong B, Sevastik B, Sevastik J, Hedlund R: Early three dimensional changes in scoliosis. In International Symposium on 3-D Scoliotic Deformities joined with the VIlth International Symposium on Spinal Deformity and Surface Topography. Edited by: Dansereau J. Ėdition de l'École Polytechnique de Montrēal:Gustav Fischer Verlag; 1992:498-504.

185. Taylor TFK, Melrose J: The role of the intervertebral disc in adolescent idiopathic scoliosis. In Etiology of Adolescent Idiopathic Scoliosis: Current Trends and Relevance to New Treatment Approaches, State of the Art Reviews: Spine. Volume 14. Edited by: Burwell RG, Dangerfield PH, Lowe TG, Margulies JY. Philadelphia, Hanley 2000:(2):359-369.

186. Roberts S, Caterson B, Urban JPG: Structure and composition of the cartilage end plate and intervertebral disc in scoliosis. In Etiology of Adolescent Idiopathic Scoliosis: Current Trends and Relevance to New Treatment Approaches, State of the Art Reviews: Spine. Volume 14. Edited by: Burwell RG, Dangerfield PH, Lowe TG, Margulies JY. Philadelphia, Hanley 2000:(2):371-381.

187. Wang S, Qiu Y, Zhu Z, Ma Z, Xia C, Zhu F: Histomorphological study of the spinal growth plates from the convex side and the concave side in adolescent idiopathic scoliosis. J Orthop Surg 2007, , 2: 19

188. Day G, Frawley K, Phillips B, McPhee TB, Labrom R, Askin G, Mueller P: The vertebral body growth plate in scoliosis: a primary disturbance in growth? Scoliosis 2008, 3:3.

189. Antoniou J, Arlet V, Goswami T, Aebi M, Alini M: Elevated synthetic activity in the convex side of scoliotic intervertebral discs and endplates compared with normal tissues. Spine 2001, 26(10):E198-206.

190. Will RE, Stokes IA, Qiu X, Walker MR, Sanders JO: Cobb angle progression in adolescent scoliosis begins at the intervertebral disc. Spine (Phila Pa 1976) 2009, 34(25):2782-6.

191. Wang S, Qiu Y, Ma Z, Xia C, Zhu F, Zhu Z: Expression of Runx2 and type X collagen in vertebral growth plate of patients with adolescent idiopathic scoliosis. Connect Tissue Res 2010, 51(3):188-96.

192. Burwell RG, Dangerfield PH, Freeman BJC: Concepts on the pathogenesis of adolescent idiopathic scoliosis. Bone growth and mass, vertebral column, spinal cord, brain, skull, extra-spinal left-right skeletal length asymmetries, disproportions and molecular pathogenesis. Stud Health Technol Inform 2008, 135:3-52.

193. Cheng JC, Tang NL, Yeung HY, Miller N: Genetic association of complex traits: using idiopathic scoliosis as an example. Clin Orthop Relat Res 2007, 462:38-44

194. Gao X, Gordon D, Zhang D, Browne R, Helms C, Gillum J, Weber S, Devroy S, Swaney S, Dobbs M, Morcuende J, Sheffield V, Lovett M, Bowcock A, Herring J, Wise C: CHD7 gene polymorphisms are associated with susceptibility to idiopathic scoliosis. Am J Hum Genet 2007, 80(5):957-65.

195. Ward K, Ogilvie JW, Singleton MV, Chettier R, Engler G, Nelson LM: Validation of DNA-based prognostic testing to predict spinal curve progression in adolescent idiopathic scoliosis. Spine (Phila Pa 1976) 2010, 35(25):E1455-64

196. Miller NH: Idiopathic scoliosis: cracking the genetic code and what does it mean? J Pediatr Orthop 2011, 31(1 Suppl):S49-52.

197. Sharma S, Gao X, Londono D, Devroy SE, Mauldin KN, Frankel JT, Brandon JM, Zhang D, Li QZ, Dobbs MB, Gurnett CA, Grant SF, Hakonarson H, Dormans JP, Herring JA, Gordon D, Wise CA: Genome-wide association studies of adolescent idiopathic scoliosis suggest candidate susceptibility genes. Hum Mol Genet 2011, 20(7):1456-66.

198. Ogilvie J: Adolescent idiopathic scoliosis and genetic testing. Curr Opin Pediatr 2010, 22(1):67-70

199. Ogilvie JW: Update on prognostic genetic testing in adolescent idiopathic scoliosis (AIS). J Pediatr Orthop 2011, 31(1 Suppl):S46-8.

200. Guo X, Chau W-W, Chan Y-L, Cheng J-Y-C: Relative anterior spinal overgrowth in adolescent idiopathic scoliosis. Results of disproportionate endochondral-membranous bone growth. J Bone Joint Surg Br 2003, 85-B:1026-31.
201. Guo X, Chau W-W, Chan YL, Cheng J-C-Y, Burwell RG, Dangerfield PH: Relative anterior spinal overgrowth in adolescent idiopathic scoliosis result of disproportionate endochondral-membranous bone growth? Summary of an electronic focus group debate of the IBSE. Eur Spine $J$ 2005, 14:862-73.

202. Gu SX, Wang CF, Zhao YC, Zhu XD, Li M: Abnormal ossification as a cause the progression of adolescent idiopathic scoliosis. Med Hypotheses 2009, 72(4):416-7.

203. Yang Z, Xie Y, Li M: Three-dimensional spring model: a new hypothesis of pathogenesis of adolescent idiopathic scoliosis. Med Hypotheses 2009, 73(5):709-13.

204. Castelein RM, van Dieën JH, Smit TH: The role of dorsal shear forces in the pathogenesis of adolescent idiopathic scoliosis - a hypothesis. Med Hypotheses 2005, 65:501-508.

205. Janssen MM, Kouwenhoven JW, Castelein RM: The role of posteriorly directed shear loads acting on a pre-rotated growing spine: a hypothesis on the pathogenesis of idiopathic scoliosis. Stud Health Technol Inform 2010, 158:112-7.

206. Roth M: Idiopathic scoliosis from the point of view of the neuroradiologist. Neuroradiol 1981, 21:133-138.

207. Porter RW: The pathogenesis of idiopathic scoliosis: uncoupled neuroosseous growth? Eur Spine J 200, 10:473-481.

208. Chu WCW, Man GCW, Lam WWM, Yeung BHY, Chau WW, Ng BKW, Lam T$p$, Lee K-m, Cheng JCY: Morphological and functional electrophysiological evidence of relative spinal cord tethering in adolescent idiopathic scoliosis. Spine 2008, 31:673-80

209. Chu WCW, Lam WWM, Ng BKW, Lam T-p, Lee K-m, Guo X, Cheng JCY, Burwell RG, Dangerfield PH, Jaspan T: Relative shortening and functional tethering of spinal cord in adolescent scoliosis - Result of asynchronous neuro-osseous growth? Summary of an electronic focus group debate of the IBSE. Scoliosis 2008, 3:8

210. Chu WC, Rasalkar DD, Cheng JC: Asynchronous neuro-osseous growth in adolescent idiopathic scoliosis-MRI-based research. Pediatr Radiol 2011 , 41(9):1100-11.

211. Lao LF, Shen JX, Chen ZG, Wang YP, Wen XS, Qiu GX: Uncoupled neuroosseous growth in adolescent idiopathic scoliosis? A preliminary study of 90 adolescents with whole-spine three-dimensional magnetic resonance imaging. Eur Spine J 2011, 20(7):1081-6.

212. Shi L, Wang D, Chu WC, Burwell GR, Wong TT, Heng PA, Cheng JC: Automatic MRI segmentation and morphoanatomy analysis of the vestibular system in adolescent idiopathic scoliosis. Neuroimage 2011, 54(Suppl 1):S180-8.

213. Wang D, Shi L, Chu WC, Burwell RG, Cheng JC, Ahuja AT: Abnormal cerebral cortical thinning pattern in adolescent girls with idiopathic scoliosis. Neuroimage 2011

214. Herman R, Mixon J, Fisher A, Maulucci R, Stuyck J: Idiopathic scoliosis and the central nervous system: a motor control problem. The Harrington Lecture, 1983. Scoliosis Research Society. Spine 1985, 10(1):1-14.

215. Doménech J, Tormos JM, Barrios C, Pascual-Leone A: Motor cortical hyperexcitability in idiopathic scoliosis: could focal dystonia be a subclinical etiological factor? Eur Spine J 2010, 19(2):223-30.

216. Domenech J, García-Martí G, Martí-Bonmatí L, Barrios C, Tormos JM, PascualLeone A: Abnormal activation of the motor cortical network in idiopathic scoliosis demonstrated by functional MRI. Eur Spine J 2011, 20(7):1069-78.

217. Burwell RG, Aujla RK, Grevitt MP, Randell TL, Dangerfield PH, Moulton A, Anderson SI: Is scoliosis curve initiation and progression contributed to by dysfunction of somatosensory, somatomotor, and/or sympathetic mechanisms? New observation and interpretation for the pathogenesis of right thoracic adolescent idiopathic scoliosis [abstract]. Clin Anat 2011, 24(3):384-5.

218. Veldhuizen AG, Wever DJ, Webb PJ: The aetiology of idiopathic scoliosis: biomechanical and neuromuscular factors. Eur Spine J 2000, 9(3):178-84.

219. Burwell RG, Freeman BJC, Dangerfield PH, Aujla RK, Cole AA, Kirby AS, Polak F, Pratt RK, Webb JK, Moulton A: Etiologic theories of idiopathic scoliosis: neurodevelopmental concept of maturational delay of the CNS body schema ("body-in-the-brain"). Stud Health Technol Inform 2006, 123:72-9, and J Bone Joint Surg Br 2008, 90-B:Supp II, 434.

220. Qiu Y, Sun GQ, Zhu F, Wang WJ, Zhu ZZ: Rib length discrepancy in patients with adolescent idiopathic scoliosis. Stud Health Technol Inform 2010, 158:63-6. 
221. Zhu F, Chu WC, Sun G, Zhu ZZ, Wang WJ, Cheng JC, Qiu Y: Rib length asymmetry in thoracic adolescent idiopathic scoliosis: is it primary or secondary? Eur Spine J 2011, 20(2):254-9.

222. Grivas TB, Vasiliadis ES, Triantafyllopolous G, Kaspiris A: A comprehensive model of idiopathic scoliosis (IS) progression, based on the pathobiomechanics of the deforming "three joint complex". Scoliosis 2009, 4(Suppl2):010

223. Machida M, Dubousset J, Imamura Y, Miyashita Y, Yamada T, Kimura J: Melatonin. A possible role in pathogenesis of adolescent idiopathic scoliosis. Spine 1996, 21(10):1147-52.

224. Machida M: Cause of idiopathic scoliosis. Spine 1999, 24(24):2576-2583.

225. Dubousset J, Machida M: Possible role of the pineal gland in pathogenesis of idiopathic scoliosis: experimental and clinical studies. Bull de l'Acad Nat de Méd 2010, 185:593-602, discussion 602-604.(French).

226. Girardo M, Bettini N, Dema E, Cervellati S: The role of melatonin in the pathogenesis of adolescent idiopathic scoliosis (AIS). Eur Spine J 2011, , Suppl 1: S68-74.

227. Moreau A, Wang DS, Forget S, Azeddine B, Angeloni D, Fraschini F Labelle H, Poitras B, Rivard C-H, Grimard G: Melatonin signaling dysfunction in adolescent idiopathic scoliosis. Spine 2004, 29(16):1772-1781.

228. Letellier K, Azeddine B, Blain S, Turgeon I, Wang da S, Boiro MS, Moldovan F, Labelle H, Poitras B, Rivard CH, Grimard G, Parent S, Ouellet J, Lacroix G, Moreau A: Etiopathogenesis of adolescent idiopathic scoliosis and new molecular concepts. Med Sci (Paris) 2007, 23(11):910-6.

229. Moreau A, Turgeon I, Samba Boiro M, Azeddine B, Franco A, Labelle H, Poitras B, Rivard CH, Grimard G, Ouellet J, Parent S, Cheng JC, BraydaBruno M: Clinical validation of a biochemical test for adolescent idiopathic scoliosis: an International Collaborative 19. Consortium [Abstract]. Eur Spine J 2008, 17:768-769.

230. Akoume MY, Azeddine B, Turgeon I, Franco A, Labelle $H$, Poitras B, Rivard $\mathrm{CH}$, Grimard G, Ouellet J, Parent S, Moreau A: Cell-based screening test for idiopathic scoliosis using cellular dielectric spectroscopy. Spine (Phila Pa 1976) 2010, 35(13):E601-8.

231. Szalay EA, Bosch P, Schwend RM, Buggie B, Tandberg D, Sherman F: Adolescents with idiopathic scoliosis are not osteoporotic. Spine 2008, 33(7):802-6.

232. Zhuang Q, Li J, Wu Z, Zhang J, Sun W, Li T, Yan Y, Jiang Y, Zhao RC, Qiu G: Differential proteome analysis of bone marrow mesenchymal stem cells from adolescent idiopathic scoliosis patients. PLoS One 2011, 6(4):e18834.

233. Kindsfater $K$, Lowe $T$, Lawellin D, Weinstein D, Akmakjian J: Levels of platelet calmodulin for the prediction of progression and severity of adolescent idiopathic scoliosis. J Bone Joint Surg Am 1994, 76(8):1186-92.

234. Lowe TG, Lawellin D, Smith D, Price C, Haher T, Merola A, O'Brien M: Platelet calmodulin levels in adolescent idiopathic scoliosis. Do the levels correlate with curve progression and severity? Spine 2002, 27(7):768-775

235. Lowe TG, Burwell RG, Dangerfield PH: Platelet calmodulin levels in adolescent idiopathic scoliosis: can they predict curve progression and severity? Summary of an electronic focus group debate of the IBSE. Eur Spine J 2004, 13:257-265

236. Burwell RG, Dangerfield PH: Pathogenesis of progressive adolescent idiopathic scoliosis. Platelet activation and vascular biology in immature vertebrae: an alternative molecular hypothesis. Acta Orthop Belg 2006, 72:247-260.

237. Burwell RG, Freeman BJ, Dangerfield PH, Aujla RK, Cole AA, Kirby AS, Pratt RK, Webb JK, Moulton A: Etiologic theories of idiopathic scoliosis: enantiomorph disorder concept of bilateral symmetry, physeally-created growth conflicts and possible prevention. Stud Health Technol Inform 2006, 123:391-7.

238. Burwell RG, Aujla RK, Grevitt MP, Randell TL, Dangerfield PH, Cole AA Kirby AS, Polak FJ, Pratt RK, Webb JK, Moulton A: Upper arm length model suggests a transient asymmetry process in the pathogenesis of right thoracic adolescent idiopathic scoliosis (RT-AIS) in girls [abstract]. Clin Anat 2011, 24(3):384

239. Burwell RG, Aujla RK, Grevitt MP, Randell TL, Dangerfield PH, Cole AA, Kirby AS, Polak FJ, Pratt RK, Webb JK, Moulton A: Right thoracic adolescent idiopathic scoliosis (RT-AIS) in girls: Abnormal bilateral asymmetry of upper limb lengths involves forearm-with-hands as well as upper arms [abstract]. Clin Anat 2011, 24(4):530.
240. Burwell RG, Aujla RK, Grevitt MP, Randell TL, Dangerfield PH, Cole AA, Kirby AS, Polak FJ, Pratt RK, Webb JK, Moulton A: A transient, or resolving, bilateral asymmetry process in the pathogenesis of right thoracic adolescent idiopathic scoliosis in girls, suggested by findings of upper arm length asymmetry related to age, curve severity, and years after estimated menarcheal age [abstract]. 12th International Phillip Zorab Symposium, Royal College of Surgeons, London 2011, 60.

241. Burwell RG, Grevitt MP, Randell TL, Dangerfield PH, Aujla RK, Cole AA, Pratt RK, Webb JK, Moulton A, Anderson SI: Abnormal bilateral skeletal asymmetries and their putative genetic and epigenetic origins in enantiomorphic growth plates of girls with adolescent idiopathic scoliosis (AIS) [abstract]. Ckin Anatt

242. Liu Z, Tam EM, Sun GQ, Lam TP, Zhu ZZ, Sun X, Lee KM, Ng TB, Qiu Y, Cheng JC, Yeung HY: Abnormal Leptin Bioavailability in Adolescent Idiopathic Scoliosis - an Important New Finding. Spine (Phila Pa 1976) 2011.

243. Burwell RG, Aujla RK, Grevitt MP, Randell TL, Dangerfield PH, Moulton A, Anderson SI: A new approach to the pathogenesis of adolescent idiopathic scoliosis: interaction between risk factors involving a diverse network of causal developmental pathways [abstract]. Clin Anat 2011, 24(3):384.

244. Bibby SR, Meir A, Fairbank JC, Urban JP: Cell viability and the physical environment in the scoliotic intervertebral disc. Stud Health Technol Inform 2002, 91:419-21.

245. Meir A, McNally DS, Fairbank JC, Jones D, Urban JP: The internal pressure and stress environment of the scoliotic intervertebral disc-a review. Proc Inst Mech Eng H 2008, 222(2):209-19.

246. Pearson H: Epidemiology: Study of a lifetime. Nature 2011, 471(7336):20-4.

247. Barabási AL: Network medicine-from obesity to the "diseasome". N Engl J Med 2007, 357(4):404-7.

248. Barabasi AL, Gulbahce N, Loscalzo J: Network medicine: a network-based approach to human disease. Nat Rev Genet 2011, 12(1):56-68.

249. Vidal M, Cusick ME, Barabási AL: Interactome networks and human disease. Cell 2011, 144(6):986-98.

250. Bonetta L: Protein-protein interactions: Interactome under construction. Nature 2010, 468(7325):851-4.

251. Suhre K, Shin SY, Petersen AK, Mohney RP, Meredith D, Wägele B, Altmaier E, CARDIoGRAM, Deloukas P, Erdmann J, Grundberg E, Hammond CJ, de Angelis MH, Kastenmüller G, Köttgen A, Kronenberg F, Mangino M, Meisinger C, Meitinger T, Mewes HW, Milburn MV, Prehn C, Raffler J, Ried JS, Römisch-Margl W, Samani NJ, Small KS, Wichmann HE, Zhai $\mathrm{G}$, et al: Human metabolic individuality in biomedical and pharmaceutical research. Nature 2011, 31;477(7362):54-60.

252. Blakemore $\mathrm{C}$ : Why the gene revolution has been postponed. The Times 2011, 33.

doi:10.1186/1748-7161-6-26

Cite this article as: Burwell et al:: Adolescent idiopathic scoliosis (AIS), environment, exposome and epigenetics: a molecular perspective of postnatal normal spinal growth and the etiopathogenesis of AIS with consideration of a network approach and possible implications for medical therapy. Scoliosis 2011 6:26.

\section{Submit your next manuscript to BioMed Central and take full advantage of:}

- Convenient online submission

- Thorough peer review

- No space constraints or color figure charges

- Immediate publication on acceptance

- Inclusion in PubMed, CAS, Scopus and Google Scholar

- Research which is freely available for redistribution

Submit your manuscript at www.biomedcentral.com/submit
C Biomed Central 